\title{
He whakaaro moo te reo Maaori: Some thoughts about the Maori language
}

\author{
Abstract \\ future emphases. \\ Contents \\ 1 Background \\ 2 Homes and Locales \\ 3 Language leadership and direction \\ 4 Identity and Property \\ 5 Literacy \\ 6 Language Leaps \\ 7 Concluding comments \\ Bibliography
}

This paper considers the language from several points of view including leadership, identity and literacy. Attention is given to possibilities for language development, recent literature and 


\section{Background}

I te tau 2000 ka haere au ki te Mea a Sina ki Apia ki te koorero moo te reo Maaori.

Ko taaku koorero ka haangai teenaa ki te reo irirangi me ngaa mahere ako. I mua noa o teenaa kua mea atu au teeraa pea he nuku i te maatauranga moo te reo naa te ipurangi me te pouwhakaata (Cleave 1999).

In 2000 I was invited to the Samoan Millennium in Apia to talk about Te Reo Maori. I wrote a paper looking at the state of Te Reo Maori and it featured the importance of radio and educational strategies. Not long before that I had suggested that the internet and television could change the way we knew Te Reo Maori (Cleave 1999).

Mai i teeraa waa kua koorero au moo te reo me te mahi paaho. Ko taku pukapuka Te Haere o te Reo, i puta ake teenaa i te tau 2009, aa, kua whakahou au i teenaa i eetahi tau mai i teenaa waa. Ko te pukapuka, Iwi Station e whai ana teenaa i te mahi paaho i ngaa reo e rua, aa, i teenaa tau hoki ka puta ake teetahi tuhinga naaku, Seen Heard, Written, Read ki tekaharoa.com. Ko te kaupapa o teenaa pepa ko te mahi tuhi, aa, ka whai anoo au i teenaa ki koonei. Mai i teenaa waa kua puta mai eetahi tuhinga ki tekaharoa.com, i hea raanei, $i$ te reo Maori i eetahi waa.

Since then I have published regularly about the language and about broadcasting. My grammar, Te haere o te reo appeared in 2009 and has been updated several times since then. Books like Iwi Station have considered Maori broadcasting in Te Reo Maori as well as English and articles like Seen, Heard Written and read, also from 2009, talk about literacy, one of the themes of this paper. That article began a series in tekaharoa.com using the reo or about it and this article is a continuation of that style of work. 
I Iwi Station ka koorero au moo Streamcom. he kamupene e awhina ana i te reo irirangi Maori moo te ipurangi me nga mea rorohiko. He waahi pai pea teenaa mo te tipuranga o te reo, aa, ko teeraa pea, he 'arc', he hononga o eetahi mea whakakookiri i te reo. Naa Streamcom te mea e kiia nei ko Punga Net me ngaa rorohiko tino pai rawa. Ki tooku whakaaro kaaaore anoo kia taea ai te puaawaitanga rawa o teenei engari e ohotia teenei pea e ngaa mea peenaa i ngaa 'apps'.

In Iwi Station I spent considerable time on Streamcom, a company that helps Maori radio with the internet and other IT matters. This is potentially a language development area and could become what I later call an 'arc', a combination of matters that advances the reo. Through Streamcom the iwi stations have punga net and a state of the art technology. This has not, I believe, so far been used to its potential but perhaps it is a 'sleeper' that may ne awoken at a later stage perhaps through the use of apps and the like.

I teenei ao o ngaa mea rorohiko hou, hononga hou hoki, he rahi pea ngaa mea e taea (McKenzie McCrae me Poia 2010, McKenzie me Poia 2014). Ka whakaarongia ngaa waka e taraiwa ana kaaore he kaihautu tangata. Mai i a Google eenaa. Ko ngaa reo peenaa i a Fortran, Erlang raanei, ko te aahua e tuu noa atu eenaa i ngaa taangata i eetahi waa. Kaaore e taea pea te koorero peenaa moo te reo Maaori i teenei waa, engari...

In this world of new apps, new digital combinations (McKenzie McCrae and Poia 2010, Mckenzie and Poia 2014) all sorts of things are possible. Cars developed outside the auto industry by internet companies like Google drive themselves. Languages like fortran or erlang seem, with only a little assistance from people to talk themselves. Along with other languages Maori could develop in various ways in this quarter, none of them strictly predictable at this stage.

Inakuanei ka tiro anoo au ki eenei mea katoa. He aha ngaa rerekeehanga mai i teenaa waa? 
Recently I looked at all this again. What has changed in the period since my 1999 paper in He Tuhinga Aronui about te reo and the internet?

I te mea tuatahi kei te piirangi au ki te whakaaro moo ngaa puutake o tooku whai anoo i te reo inaaianei, aa, ki muri o teenaa ki te hoki ki ngaa mea rerekee.

First of all I want to look at why I have recently been looking at Te Reo again and then I want to come back to what has changed.

E mahi ana au hei kaiwhakapaaho i te reo Maaori, aa, kua paaho au i te reo i ngaa waa katoa moo eetahi tau.

I work as a broadcaster in Maori radio and have been broadcasting in Te Reo exclusively for some years.

I a au e mahi ana kua tuutaki au i eetahi whakaaro moo te reo, aa, $i$ te nuinga o ngaa waa kua maatau au ki te whakatinana i eenei mea, kua waananga raanei au $i$ te peenaa.

Over the course of work I have encountered various theories to do with the language and invariably I have tried to put them into practice or at least thought about doing so.

I te nuinga o ngaa waa he waahi marino teenei engari he whatihanga kee i mua noa i te wanawana mo te Rautaki Reo Maori i te timatahanga o 2014.

Generally this is a fairly quiet area but there has been a break with a recent buzz of excitement about the Maori Language Strategy or Plan, Te Rautaki Reo Maori, in early 2014. 
I ngaa teihana reo Maaori e kore e kore e kitea te whakatikahanga moo ngaa paahotanga. Kai te koorero au moo ngaa 'Prep Sheets' ia wiki, ia wiki ki te whakaaatu i nga take me ngaa mahere kia taea ai peenaa i eeraa moo te reo.

At a Maori Language Radio Station there is always necessary and critical preparation to do involving Te Reo as a matter of course. I am talking about the Prep Sheets that broadcasters at our station do weekly that show the various topics and strategies to be employed including those pertaining to Te Reo.

Ko teetahi wahanga o teenaa mahere he hokihanga ki te haere o ngaa mahi. Hei tauira, i ngaa uruhanga me ngaa wehenga ki ngaa waa koorero. I eenaa waa ka whai whakataukii au, aa ka whakahou au i eenei e hoohaa haere ana. Ko teetahi mea ko te ipurangi. Ka whakatau au i eetahi mea ki te whaarangi ipurangi o te teihana, araa, Ko Facebook i te reo, i ngaa whakaaaturanga pikitia, i ngaa tuhinga hoki. Ko te whakaaro mo eenaa mea he wahanga o te mahi whakatikatika hoki.

Some of that strategy is a response to how things are going. For example, at entries and

exits to voice breaks I use metaphors and change these from time to time as their effect wears thin. Another feature of work in progress is the use of the internet. I post on Facebook on the station's page in Te Reo, video. text and audio and the evaluation of that is part of the Prep.

Aapiti atu i te mahi mai i teenaa wiki ki teenaa i nga 'Prep Sheets 'kua horahora te koorero nei ki teenaa waa ako, teenaa whakawhiti koorero raanei. Teeraa pea raanei he whakaaro eenei moo te reo kua paanuitia e au kua kitea raanei i te ipurangi. I te nuinga o ngaa waa kua whai au $i$ eenei whakaaro. E whai nei ngaa whakaaro tonu, te whakatinanatanga o eenaa whakaaro me eetahi paatai moo te 
reo $\mathrm{i}$ teetahi kauwhata waananga peenaa $\mathrm{i}$ teenaa $\mathrm{i}$ mua o teenaa paahotanga, teenaa raanei.

As well as in the week to week work on the Prep Sheets the points reflected upon below have been set out in interviews and in training seminars. Or they are ideas of language transmission that I have read about or come across on the net. In nearly all cases I have taken the advice and tried it or at least asked questions about it. What follows is a mix of the advice itself, the implementation of it and also questions about the use of Te Reo considered through the kind of critical grid that you apply to things before you go on air.

Ko te tirohanga whaanui moo teenei ko te rangahau me te whakataa moo te reo i teetahi waa roa (eg 1975, 1977, 1980, 1999, 2000 etc). Kua taea e au te mahi tuhi e kitea nei i teenei tuhinga; he waahanga $\mathrm{i}$ te reo me teetahi waahanga e whai naa $i$ te reo Paakehaa e paneke pea $i$ te mea tuatahi. Kaaore teenei $\mathrm{i}$ te oorite tonu ki taa Baker raua ko Jones i taa raaua hiikoitanga tuarima;

Stage Five: Literacy in the minority language. Need to support literacy movements in the minority language particularly when there is no government support.

engari ko teenei pea he hiikoitanga ki teeraa aronga. A muri nei e paataingia meenaa he rahi te tautoko mai $\mathrm{i}$ te kaawanatanga, i ngaa kura i hea raanei moo te mahi tuhi ki te reo.

The broader context to all this is research and publication over a long period in areas to do with Te Reo (eg 1975, 1977 and on). I have developed a style where a paragraph is set down in Maori and then a paragraph follows in English, sometimes translating word for word but always attempting to go over the same ground. While this may not have been exactly what the language theorists Baker and Jones (1988:188) meant in their Stage Five as stated in Ngapo 2014:185); 
Stage Five: Literacy in the minority language. Need to support literacy movements in the minority language particularly when there is no government support.

it is, perhaps, a step in that direction. Later it is asked whether there is enough government support as well as general attention in teaching and elsewhere for literacy in te reo.

Kia hoki ai taatou ki eetahi tau e rua pea ki te taapere-aahuarahi i whakatinanatia naa e te Taura Whiri, he koorero ki reira moo Te Raangai Reo Maaori; he roopu mahi e koorero Maaori ana e whakahaere raanei hoki pea i te reo.

Going back a couple of years to the roadshow put together by Te Taura Whiri and others about Te Rautaki Reo Maori there was talk there of Te Rangai Reo Maori, an industry or vocational group of speakers and administrators of Te Reo.

Ka hono au i teenei hui nuku ki Whaanganui i 2010. Ka paataitai au i te kupu 'raangai', inahoki ki a au i mua ko te aro o teenaa ko te hiki ake, ko teenaa te aronga nui ki a au nei. I muri i te hui ka koorero au i te reo irirangi moo te aahua o te haapori me te aahua o nga tari me te whakahaerenga o te reo.

I caught up with it in Whanganui in 2010. I worried at that term, rangai, as to me previously it had always meant a raising up as its primary or main meaning. And afterwards on air I went on about the sociology of a language bureaucracy looking, in vain, it seemed to me at the time, for a response.

I te tau i whai mai ki teetahi huinga o Te Maangai Paaho ki Tuuturu Puumau, Rangitaane Pa, Awapuni i te Hune, 172013 e rua ngaa koorero i whakatakotongia hei mounu koorero. I reira eetahi o te poari o TMP me eetahi kaimahi hoki i kookiri ai i te kaupapa. 
The next year, at a Te Mangai Paho Cluster Group hui held at Tuturu Pumau dining complex Rangitaane Pa, Awapuni on June $7^{\text {th }} 2013$ two papers were presented as part of a general discussion with TMP board members and employees facilitating.

Ko teetahi koorero ka haangai teenaa ki ngaa hapa aa reo $\mathrm{i}$ nga paahotanga. Ko teenaa he arotake rawe moo nga mea e kore e tika kia meatia, aa, kaaore he whakaiti i ngaa taangata.

One paper looked at common mistakes made in radio commentary. This was an excellent review of what not to do without being overly critical of people involved.

Ko teetahi atu koorero, ka whai teenaa $\mathrm{i}$ te mea $\mathrm{e}$ moohiotia naa ko Zepa Theory. Ko teetahi o ngaa mea ki te mahere Zepa ko te nukuranga i nga waa o mua ki te waa o naaianei. Ko te wao o mua me oona aahua uu me te waa o naaianei me oona whakawhiti o te waa tonu. Ka paatai mai teetahi kaikoorero 'He aha te whakaaro moo te hoa rangatira e whakaoho i a koe i nga kupu, 'Tihei mauri ora!'.

As for another talk it concerned what is known as Zepa Theory. One of the features of Zepa theory is the shift from a past centred attitude to a present centred one. The past with its formalities and the present with its casual, informal and impromptu give and take, its immediacies and relevancies. A presenter asked what would it be like to be woken up by a partner with the phrase, 'Tihei mauri ora!'.

Ko te mea Zepa naa e haere tahi ana teenaa, kaaore raanei me te karanga kia tootika ai te reo. He whakapae teenei ki Te Karere i eetahi waa (Te Karere April 15 2014). Engari ko ngaa mea o te waa he mea uaua hoki i eetahi waa. Ahakoa te ngaawari o te koorero he uaua kee ngaa mea e whakaarongia nei. 
Zepa theory may or may not go with the call to keep the language simple most often levelled at Te Karere and other news shows in Te Reo (Te Karere April 15 2014). Current events may be just as complex and call for even more vocabulary than past events. Informal is not necessarily more simple than formal.

Ko eenei koorero e rua he rawe, aa, he tohu pai teenaa moo TMP. Ko te mahere o TMP kia haangai ai te reo ki nga mea o te raa, aa, kia kore e puta mai nga hapa hoki.

These two papers were excellent and they reflected well on the TMP team. The Te Mangai Paho plan was to make Te Reo more about experience and to get rid of slack grammar.

Ko te koorero moo ngaa hapa-aa-reo, ka haere teenaa $\mathrm{i}$ teetahi raarangi o nga hee noa peenaa i te '-e' me te '-ngia'. Ko teenei, he mahi whakatika noa. I eetahi aahua ka haangai teenei pea ki aa Kelly (2014 258-9). Ko te whakaaro nui ki koonei he nui te toro o eetahi hapa. Engari he raru pea i te moohio o eenei. Kai te koorero a Karena Kelly moo te 'e' me te 'i' (2014:259). Kai te koorero a Kelly moo ngaa roopu e rua, L1 me L2. He aahua matatau ki te reo te roopu L1, he mea tiimata noa te roopu L2. Engari raa, ko te paatai e tika ana kia whakatakotongia, he hapa ki koonei i nga akoranga? E ai ki a Kelly, ko nga kaikoorero L1;

see the big picture but by overlooking the details they see a picture that is often out of focus. The L2 speakers instead may see a much smaller picture but with greater clarity.

Kelly 2014:259

he tinihanga teenei? He aha te pai o te wehenga o L1 me L2?

The grammar discussion proceeded from a list of common mistakes or traps such as the use of the passive ending without the agentive particle 'e' behind it. This was a clean up and tidy up exercise. In some ways this might relate to arguments by Kelly (Kelly, 2014 258-9). The general idea here 
is that some grammatical practices or mistakes are quite widespread. But there may be difficulties in how these are understood. Karena Kelly (2014:259) talks about the use of the particles 'e' and 'i'. Kelly is considering two groups of speakers, L1 and L2, the former with more experience of te reo than the latter. Interestingly Kelly says that L1 speakers in her study

see the big picture but by overlooking the details they see a picture that is often out of focus. The L2 speakers instead may see a much smaller picture but with greater clarity.

Kelly 2014:259

This seems like sophistry and one wonders what the point of a distinction between L1 and L2 is.

Ko te nuku i te Maaui ki te Matau i te mahere Zepa ko teenei teetahi mea moo ngaa kaikoorero me ngaa kaiwhakahaere o te reo. He rahi tooku waa koorero i te reo irirangi moo teenei, aa, he mea nui te pepa moo Zepa ki a au inahoki i ai ki a au he hononga ki taaku mahi moo te kanikani Maaori o naaianei.

The shift from Left to Right in Zepa theory, is one that administrators and broadcasters alike might well respond to. On air I spent a fair bit of time talking about this and in fact the Zepa paper meant a lot to me as I took the ideas there and considered them along with others in my work on Maori contemporary dance (Cleave 2014).

I teenaa waa ka whakahoungia te mahere Zepa $\mathrm{i}$ te putahanga o Te hua o te reo Maori (Higgins, Rewi and Olsen Reeder 2014).

Apiti atu i ngaa mea i koorerongia ki runga ka tuhi a Higgins me Rewi moo te nuku i te Upoko Tuarua ki te Upoko Tuatoru o te te Tiriti o Waitangi (Higgins me Poia 2014:31)

And then Zepa theory was updated, for me at least with the appearance of The value of the Maori Language (ed Higgins, Rewi and Olsen Reeder 2014). As well as the points mentioned above Higgins and Rewi in their essay on Zepa in the 2014 
collection talk about a shift from Article Two to Three of the Treaty of Waitangi (Higgins and Poia 2014:31).

He rahi, he rerekee hoki te aro o te Reo me te Tiriti ki teenaa kairangahau, teenaa raanei. E ai ki a John McCaffery ko ngaa Paakeha ngaa teina, ko ngaa Maaori ngaa tuakana i raro $\mathrm{i}$ te maru o te Tiriti me eetahi mea hoki. E tika ana pea kia whakaarongia teenaa $i$ te taha o taa Karena Kelly rangahau moo ngaa roopu kaikoorero L1, L2 hoki me taana koorero mo too Karetu moo ngaa mea reo tuarua (2014:257). Aa muri e koorerongia te whakaaro, he roopu nui pea teenei hai roopu kaikorero (Kelly in Higgins ed 2014:257). Ko teetahi tirohanga whaanui moo ngaa rawa ko taa Barber (1995).

Te Reo and Te Tiriti are put together in various ways by commentators. John McCaffery sees Pakeha as teina and Maori as tuakana under the Treaty with regard to the reo as with other things (McCaffery on Radio Waatea April 2014). McCaffery's approach might be considered alongside that of Karena Kelly' L1 and 12 research and her mention of Karetu's opinion of second language learners (Kelly in Higgins ed 2014:257). Later it is argued that this group might be important as a set of speakers. Amongst others a wider perspective on values might be gained through a reading of Benjamin Barber's book on tribalism and globalisation (Barber 1995).

Moo te whakauu ki ngaa waa o mua, o ngaa mea e aata maharatia, ko te kupu e mau mai i a Kenneth Foote me Sharon Mazer ko memorialisation, aa, ka hari au i te kupu classicisation ki te koorero. Ko Foote e aro ana ia ki ngaa waa me ngaa waahi, ko au ka koorero hoki au moo ngaa waahi i te whakaaro e meatia nei hai 'locale theory' i a au e koorero ana moo Foote. Ko te koorero moo te 'locale' te waahi, me kii, naa Merata Kawharu (2010), he mea haangai hoki teenaaa ki te kaupapa ki koonei. 
Regarding an emphasis on the past, on the formally remembered, Kenneth Foote and Sharon Mazer use the word memorialisation and I bring the word classicisation into the discussion (Cleave tekaharoa.com 2014). Foote's use of memorialisation is in terms of events and locales and I refer to locale theory in Geography in passing as I discuss Foote's work Locale theory as developed in the Maori context by Merata Kawharu (2010) is important in the general argument of this paper and referred to several times. 


\section{Homes and Locales}

Mai raano kua noho te reo i teenaa kaainga teenaa. E tika ana pea kia aata rangahaungia eenei inahoki ko eenei 'kaainga' he waahi moo te haere me te tipu o te reo. Teeraa pea e kitea te aahua o te reo $\mathrm{i}$ teenaa waa, teenaa $\mathrm{i}$ te rangahau peenaa. Kai ia kaainga, i eetahi aahua, he reo anoo.

There have been various 'homes', ports of call, places to live for Te Reo over the years. These might be studied as a matter of serious research as it may be that such 'homes' are responsible for the kind of language spoken and that research might yield informative characteristics of historical epochs. Each home has, in certain respects, another language.

He koohanga, he nohohanga moo te reo i koonei i mua i te haramai o Ngai Paakehaa, he waahi waananga eeraa atu i te wao koorero Maaori whaanui. Mai i teenaa waa ki waenganui o te rau tau rua tekau ko ngaa Haahi ki te Tai Tokerau, ki eetahi waahi hoki, ko te Haaahi i tuu ai hai waahi tautoko, whaangai hoki me kii, i te reo atu i nga hau kaainga. Ko nga rauna koorero peenaa i te Poukai me ngaa Tekau Maa Rua o te Ringatuu. ko eenaa eetahi waa, waahi hoki maa te reo e ora, e tipu. Ko ngaa kura Maaori eetahi waahi.

Other than the general use of Maori there were places of language development and study before contact. Since then until the mid twentieth century the Churches, especially in the North but elsewhere as well were sites where Te Reo was nurtured. Rounds of hui such as the Poukai of the Kingitanga and the Ringatu Twelfths offered other places where Maori was and is spoken and developed. The Native Schools so called also had their place and their day in nurturing and providing a space for Te Reo when elsewhere the environment was hostile.

I eetahi waa e kitea he raarangihanga o eenei kaainga. Hei tauira ko te haere o Maori hai reo wairua ki te Whare 
Paremata. teeraa pea he hononga ki reira ki ngaaa Kura Haahi peenaa i a Tiipene Kura kia whakaarongia a Shane Jones raatou ko Te Ururoa Flavell ko Hone Harawira. Ko te reo o nga kura he peenaa, he reo wairua, he reo tapere hoki. E tika ana pea maaku e kii ko au taa raatou naa mahita tapere.

Sometimes there is an alignment of these 'homes'. For example the use of Maori in Parliament as a spiritual language might have to do with the fact that a lot of the speakers went to Church Schools- St Stephens in the case of parliamentarians, Te Ururoa Flavell Shane Jones and Hone Harawira- and the reo that they were exposed to was of a religious kind as well as a performance based kind. On the latter point I should say as a matter of information that I was their drama teacher Cleave 2013.

Kei teena kaainga, teenaa, he pukapuka, he 'Paipera' moo teenaa kaainga teenaa. Ko te Paipera tonu moo te Haahi. Ko aa Hoani Waititi me Timoti Karetu pukapuka ki nga kura, ko aa John Moorfield pukapuka moo te Pouwhakaata Maaori.

Each home has had its own reading list, its own bible. The Bible itself for the church home. Hoani Waititi and Timoti Karetu's books in the schools, John Moorfield's books for Maori Television.

Mai, me kii, i te tau 1975 tae rawa ki naaianei kua uru mai te Kaawanatanga me te whakatuuranga o ngaa Koohanga Reo, ngaa Waananga, ngaa Kura Kaupapa, Language Revitalisation Centres, Te Taura Whiri, Te Maangai Paaho me, kia taea ai, Te Maataawai, te maru e piirangitia moo eenei mea reo katoa.

Since, say, 1975 until the present day the government has been involved with the establishment of Kohanga Reo, Wananga, Kura Kaupapa, Wharekura, Language Revitalisation Centres, Te Taura Whiri, Te Mangai Paho and now, if Te 
Rautaki o te Reo Maori is implemented, Te Matawai, the super ministry for Te Reo.

Ko eenei whare reo, he tari inahoki e kore e kore he whakahaerenga ki eenei. Ko te Maangai Paaho te tari moo te reo irirangi Maaori.

These language homes have been bureaucracies in the sense that people have been involved in administration as well as or as part of actually speaking te reo. Te Mangai Paho is the bureaucracy for Maori Radio.

Ko te wawata o Te Rautaki Reo Maori kia honohono eenei mea e rua; ko te maru ko Te Puna Kokiri, ko nga rohe e whitu kei raro $\mathrm{i}$ te maru he peenei $\mathrm{i}$ te aahua kaawana o te Pouwhakaata Maori. I koonei ka kitea pea te nohoanga o te reo $i$ te kaawanatanga me ngaa iwi.

Te Rautaki Reo Maori seems to put two concepts together, one being the umbrella of Te Puni Kokiri and the other being the notion of seven zones in an electoral college which is like the model used in Maori Television. The 'home' envisaged is a mix of state and, through the zones of the electoral college, iwi.

I eenei 'nohoanga' moo te reo e kitea eetahi aahua koorero. Teeraa pea ko te aronga o Zepa, he whakaaro e puta $i$ te nohoanga roa o te reo i nga Haaahi me nga marae.

Each of these 'homes', these nohoanga reo, has resulted in different styles of speech. It may be that Zepa Theory is a response to the long period when Maori was in the 'homes' of the church and the marae.

Ko te reo irirangi Maaori me te Pouwhakaata Maaori, kei te taha Matau i te mahere Zepa inahoki e whaia ana ki reira te ao o naaianei. Engari i eetahi waa e kitea te wehenga o te Matau ki te Maaui i nga teihana pouwhakaata e rua, te Pouwhakaata Maaori me Te Reo. 
Maori radio and television are, as a matter of necessity on the Right in Zepa terms, they must deal with the here and now. Having said that, as suggested elsewhere here sometimes there is a Left-Right distinction that might be drawn in Zepa terms between, say, Maori Television and the Te Reo station.

Naa teeraa pea te kaha ki te reo kawa. Teeraa hoki pea ko te reo o te kura e tino meatia i ngaa koorero ki runga reo irirangi, he tauira o te reo ki teetahi kaainga, teetahi nohoanga $\mathrm{i}$ raro $\mathrm{i}$ te maru o te Kaawanatanga. Aa, ko eenei hononga katoa he waahi moo oona anoo naa maherehere,moemoea raanei. Engari teeraa pea kaaore i te tika kia whakakootahitia ngaa moemoea o te reo me eenaa o te Kaawanatanga.

Hence perhaps the emphasis on formal as opposed to informal. And it may be that school language as mentioned throughout the interviews on the radio is a case of Te Reo finding a 'home' in the state since the 1970s, becoming, in its own way, a ward of the state. And each of these homes has had its own spins, its own ideology, its own dreams. Dreams of language ought not, perhaps, be confused with dreams of state or anything else.

Kei te taha o teenei ko te whakaaro kia noho ai eetahi roopu motuhake i eenei nohoanga, ngaa taangata haahi ki ngaa Haahi, ngaa kuramaahita me akonga ki ngaa kura, ngaa kaiwhakapaaho ki te ao paaho. Teeraa pea ko teenei teetahi puutake o te mahere Zepa inahoki ka whaia te kawa ki roo reo e nga iwi engari ka whaia te reo irirangi me te Pouwhakaata Maaori ki roo reo o te ao whaanui. He aahua anoo pea oo raatou.

Along with this is the thought that each home has its own speakers. People of the cloth especially in the Catholic Church, schoolteachers, and now radio and television people. It may be that a reason for Zepa theory comes from the idea that people speaking to follow kawa are people from the tribes. People 
following Maori radio and television, especially the latter are not or at least not necessarily. With radio and TV, in Zepa terms, on the right, then perhaps a new set of speakers are in this new home as well as, in Zepanese, being right shifters these speakers may have non-traditional identities.

Ko te waahi, he mea nui teenaa moo te reo moo te mahi tapere hoki. Me whakaaro taatou mo te reo me te tapere o te motu whaanui me te reo me te tapere o te kaainga. Ki Amerika ko te reo Paaniora te reo o te barrio i eetahi waahi, aa, i eetahi waahi peenaa i a Los Angeles ko teenei te reo o te nuinga o ngaa taangata. Engari ko te reo o Amerika ko te reo Ingarangi. Ko te mea e mohiotia naa ko locale, he mea nui rawa $i$ te waahi noa.

Locale is important for language as it is for theatre. The language and theatre of state, the theatre and language of the village. In the USA Spanish is the language of barrio and, increasingly, city in, say, Los Angeles as the percentages city wide move over fifty percent. In the USA the language of state is English. In the case of America as elsewhere locale is much more than place.

Ko te waahi, te 'locale' naa, he mea i whai ai i a Merata Kawharu (2010) i te aahua o te 'locale' o te marae, a, ka noho tika ai teenaa pea i te taha maaui o te mahere Zepa. He waahi o neheraa pea teenei.

Locale has been used by Merata Kawharu (2010) in the sense of marae locale and to some extent Kawharu's thesis aligns with the Left side of the Zepa theory. This is, perhaps, a locale of the past.

I te reo, peenaa i te tapere, ko te rawa o te reo, he mea nui teenaa (cf Higgins ma 2014:8-9). Naa te aha teenaa rawa i te reo o te tokoiti peenaa i Ngai Maaori ki Aotearoa? Ko teetahi whakautu ko te kawa me te whakamaharatanga. Kia whakaarotia te reo Paniora ki Amerika e whakataetae ana i te 
reo Paakehaa he nui ngaa rawa aa hapori. Ka haangai hoki pea te koorero moo te whakamaharatanga i ngaa raa ahurei, raa whanau, raa nui o te Haaahi me ngaa raa mahara inahoki ka taea eenei i te reo o Ngai Paniora.

In language as in theatre the value placed on language is important (cf Higgins et alia 2014:8-9). How is that value given and maintained in the case of a minority language like Maori? One answer is by ritual and memorialisation. For a competing language like Spanish in the USA, competing, that is, with English, there is high community value and the memorialisation argument may apply there as Festival Days, Family Days, Church and shared remembrances happen in Spanish.

Kai te pono eetahi hoki he wairua ki te reo. Ka whai a Waho raaua ko Arapine (in Higgins et al ed. 2014: 223) i a Taa Heemi Henare;

ko te reo te mauri o te mana Maori

There is also a belief that the Maori language has a sprituality. Waho and Arapine (in Higgins et al ed. 2014: 223) quote Sir James Henare;

ko te reo te mauri o te mana Maori

Teeraa pea e tika ana kia kitea he rawa ki te waa o naaianei, o te mahi me te whakawhiti koorero o naaiatonumainei. Ko Milroy i taana tuhinga Matua Rautia (Higgins et al 2014:197) kai te whai ia i eetahi mea tautoko i a ia e koorero ana moo ngaa kaumatua hai puu tuatahi maa ngaa tamariki ki te Koohanga Reo. He peenaa taa Milroy i teetahi whakataukii mai i a Awherika Kia pakeketia te tamaiti e te hapuu. Teeraa pea e tika ana kia aapitihia te whakaaro ko te mahi ki te kaainga o te hapuu te mea e whakakoikoi i te reo.

There might also be a value placed upon the present, on interaction and usage in the now as distinct from value placed 
upon the past. Milroy in his essay entitled Matua Rautia (Higgins et al 2014:197) implies many sources while he argues for the kaumatua as a major source for children in $\mathrm{Te}$ Kohanga Reo. Milroy's initial approach is like the African saying, that it takes a village to raise a child. One could add that it is the action in the village that keeps a language alive and kicking.

Kia tautokongia taa Milroy (op cit) kai te pukapuka Starting Points (Cleave 2009) he koorero moo te haangai o ngaa kaumatua ki te reo me ngaa tikanga. E aahei ana raatou ki te nuku ki Ahitereria, ki te haere atu i te marae ki nga Haahi, ki ngaa waa kapa haka ki hea raanei. I eetahi waahi peenaa i a Rangitaane Paa ka kitea te Kaumatua Revolution me ngaa hui nui peenaa i ngaa Haakinakina Kaumatua. Ki reira ka whakatipu, ka whakaora hoki raatou i te reo me ngaa tikanga i a raatou e aarahi hoki ana $i$ te reo i eetahi reanga.

In support of Milroy (op cit) in Starting Points (Cleave 2009) a chapter is devoted to the role of kaumatua in regard to te reo and tikanga looking at their flexibility in that they can travel to the Maori populations in Australia, function in church and kapa haka environments as well as marae settings. There is also something of a Kaumatua Revolution going on in places like Rangitaane $\mathrm{Pa}$, Palmerston North where large groups of kaumatua participate in such things as Kaumatua Olympics. This development is important as kaumatua are sustaining and developing the reo within their group as well as functioning as standard bearers for other age groups.

A muri e koorerongia he tuhinga naa Flavell i a ia e kii ana he rawa wairua too te reo $i$ te Whare Paremata. I teetahi waahi kua mea au moo te hokihanga ki teetahi 'nako wairua' (Cleave, Starting Points 2009). E tika ana kia whakaarohia hokitia ngaa rawa o te taiao me te maharatanga-aa-iwi (Goldsmith 2011, Schama 1995). Ko te whakaaro o J G A Pocock moo ngaa reo toorangapuu, ko teetahi anoo. Ko te reo Maori ki Aotearoa, he 
reo wairua kia whaia ai a Flavell, te reo o te ngaakau me te wairua?

Later a paper by Flavell is discussed where he suggests that te reo has a spiritual value in Parliament. I have elsewhere spoken about falling back on a 'mystic core' (Cleave, Starting Points 2009). There are values of nature and folk memory that might be considered as well (Goldsmith 2011, Schama 1995). The thesis of J G A Pocock regarding political languages might be considered at this point (cf Pocock, Cleave 1979). Is Maori in New Zealand the language of the wairua, as Flavell suggests, the language of the heart and of the spirit?

Kia maataungia te mahere Zepa ki Amerika kei te taha Maui te reo Paniora, te taha Matau te reo Paakehaa?

If we were to take Zepa theory and apply it to the USA then would Spanish be on the Left and English on the Right?

Ki te hau kaainga ko te reo tuuturu, kei te taha Maaui o Zepa, ko te reo o te reo irirangi, kei te taha Matau o Zepa. he reo o naaianei, o te waa tonu. Ko teenei pea he reo ki te whakakootahi te iti me rahi (cf Higgins et al moo Elizabeth Rata and Habermas 2014: 12-13)?

And back home the language of the village, te reo o te kainga, te reo tuuturu so-called, the established language is on the Left of Zepa theory and te reo paho, the language of broadcasting on Maori radio and television is on to to the right of Zepa, a language of the now, a language of change. This is a language that potentially integrates minority and majority (cf Higgins et al and their reference to Elizabeth Rata and Habermas 2014: 12-13).

Kia nuku peenaa ai te reo i te taha Maaui ki te taha Matau i runga i nga karanga o Zepa he aha te aha moo te rawa o te reo? ka whakanoa katoatia te reo? He pai ki a Higgins me Poia 
kia nuku ai te reo ki te taha matau. He aha te aha ki koonei? E ai ki a raaua;

mainstream ideologies of language status will continue to ghettoise the Maori language.(op cit 20214:31)

What does the Right Shift a la Zepa do to the value of language? Does it dememorialise it? If you take the language out of the silo (cf Higgins et al 2014:29) do you lose its integrity? Given that Higgins and Poia are talking about a default Right Shifting situation as optimal what gives here? Higgins and Poia suggest that 'mainstream ideologies of language status will continue to ghettoise the Maori language. (op cit 20214:31).

Teeraa pea ka tuu te reo Maaori i teetahi waahi reo e porohitatia naa e te reo Paakeha, te reo Hainamana me te reo Paaniora. Naa teenaa he whaaiti kee te huarahi. Naa teenaa e tika ana kia pai ai te mahi e taea i roo reo ki roo hoki i te porohita e koorerongia nei. Meenaa e whakawhaaititonutia, ka whakangoikoretonuhokitia, e taa...

Chances are that Maori up against English Spanish and Mandarin will always be confined, and, in a strict sense of the word, always be in a ghetto situation. Is the point here more to do with what is happening in the confined space, the ghetto, the silo, than the fact that it is actually confined and ringed by other languages? If what is happening is further shrinking and the language is becoming increasingly sclerotic and fragmented then there is cause for concern. If not?

Ko te whakawhiti koorero te mea nui ki a Higgins me Poia, aa, naa teenaa te tapa i a Fishman me Spolsky (op cit 2014: 16-22). He whakataetae aa reo teenei i te huarahi whaanui o te ao. Aapiti atu i teenaa ko te rahi o nga tatanga; Te Taura Whiri, Te Maangai Paaho me, ianaianei, Te Maataawai. Ko teetahi mea ko te mahi ako reo ki te Pouwhakaata Maaori. He mea hono. he mea awhina i te reo koorero teeraa? Atu o eenei 
tatanga ki te reo he aha ngaa mea i te taha Maaui, i te taha Matau raanei o Zepa?

Transmission is at a premium in Higgins and Poia and so we get Fishman and his GIDS and Spolsky (op cit 2014: 1622). They are competing in and with the mainstream. Also they are in a mix of approaches, the Taura Whiri, Te Mangai Paho, and now Te Maataawai. There is also the approach to learning te reo on Maori Television. Does it accord with and help spoken Maori? Of these approaches what is on the Left or the right in Zepa theory?

Kia hoki ai te koorero ki a Mika; i te whare tapere kai te whati hue a Mika, aa, ko toona reo he mea tautoko whakaaro, he mea tautoko i te reo o too Mika tinana. Kei hea teenei i te Wao Zepa?

To intersperse a point from a thread above, Mika in theatre, Mazer's subject, is breaking a lot of calabashes and tearing down houses of comfort in the village locale. His use of the reo is for dramatic effect, a set of speech acts to support body language. Where is this in the Zepa scheme of Left and Right?

He uu kee a Mika i aana koorero moo te aahua o te tangata. Ko May, e koorero ana ia (Higgins ma 2014:27) moo nga reo koorero whakawhiti whaanui me te reo o te tokoiti, aa, moo te aahuatanga me ngaa pakiwaitara te mea tuarua. He reo koorero te mea tuatahi, he reo whakatuu aahua te mea tuarua. Kei te rohe tuarua a Mika me taana mahi reo.

Mika makes very forceful statements about identity. May, quoted in Higgins et alia (op cit 2014:27) talks about the 'wider communication' language and the minority language and talks of the latter being about tradition and local identity. So the first is about communication and the second is about making statements, Mika's use of language being the latter. 
He tohetohe nui i waenga i a Karetu me Matthews moo teenei (Karetu 1993, Matthews 2004), aa, e tata ana teenaa ki te koorero moo Mika ki runga.

There is a very vigorous debate between Timoti Karetu and Nathan Matthews? on this that relates to the point about Mika above (Karetu 1993, Matthews 2004).

Naa teenei te kupu 'tinana' i taaku tuhinga, Memory body and Dance (2014). Kia nuku te reo ki te Matau he aha ngaa hua, aa, he aha ngaa mea e ngaro? Kia hoki te koorero kia Matthews me Karetu ka ngaro te aro ki te ate?

It is partly also why my essay Memory body and dance features a discussion of the corporeal. If Maori is Right shifted as per Zepa theory does it move into the 'wider communication' zone and directly compete- most likely lose in the process- with English and lose its purpose of being about tradition and local identity, in terms I have used of being about memorialisation and classicisation or, to come back to the discussion of Matthews $\mathrm{v}$ Karetu, lose being more about the visceral?

Teeraa pea e rere te koorero ki te tapu, te noa, te tuuturu, te noa raanei. Kai te koorero taatou moo te kaha o te kauwhata? Hai tauira i te Haahi he tapu pea te reo, aa, i te paapara kauta, teeraa pea he ngaawari, he noa pea te haere $o$ te reo. He peenei tonu a Zepa? Ka kitea te aro o te koorero i te nuku i te tuahu ki te ahi?

It may be that there are accompanying concepts, tapu and noa for example or, in this case, tuturu and noa, established and without strict or necessary frame. Are we talking about the strength and restrictions of frame? There is a sense in which Te Reo, used in the North and elsewhere is a tapu sort of thing when used in church for Karakia. Then there is a sense in which the language, say around the fire at night or in the kauta is a noa kind of a thing. People joke and laugh and 
talk about anything that comes to mind in a free ranging kind of a way. How does Right Shifting happen in such contexts? Is it as simple as moving from altar to fire?

He reo tuatoru te reo Maori ki eetahi i teenei wa i muri, me kii, i a Mangarin, Hindi raanei me te reo Paakehaa. Ko te reo Paakehaa te reo ki waenga taangata rerekee. Moo eetahi he reo anoo maa ratou e koorero ki te toa, ki te kura raanei pea, aa, ki tua o eenaa pea, ko te reo Maori. Kia whaia ai te Tiriti o Waitangi me ngaa reo e rua ki roto, he mea rerekee anoo teenaa. He ngahere uaua teenei moo te hiikoi.

Te reo is a third language to many citizens now after, say in Auckland, Mandarin or Hindi. It is not just a matter of displacing English as a medium of communication. English is the default language most of the time. And then for some there is another language in the shop or the school and then there is Maori. So a Treaty reading which yield a duality of Maori and English warps and segues into other language transitions.

He mea nui te moohio kei hea kee ngaa pito maarama, ngaa hononga hoou, ngaa torohanga hoou o te reo. Ko ngaa mea ako ana $\mathrm{i}$ te reo hei kaikoorero tuarua, tuatoru ranei e whakatinanatia he torohanga pai o te reo i a raatou? He mea pooturi i te reo raanei (cf Kelly moo Karetu 2014)?

The identification of 'bright spots' or what I call 'arcs' or 'feeder situations' or 'surround situations' below is really important though. In the conclusion a set of such growth opportunities are envisaged. Are second language learners, as Kelly, for example, citing Karetu, argues, an impediment? Or are they, potentially at least, an asset?

I a Kelly e koorero ana moo te 'e' me te 'i' ka mea ia he pai rawa te roopu L2 ki te roopu L1 moo eenei. Meenaa ka peenaa ko teenei pea he

whakaaro pai pea i nga mea o L2 e uru ana ki te reo. 
In a useful phrase when considering the passive Kelly talks about 'structural clues' (Kelly 2014: 259 in her discussion of L1 and L2 groups suggesting that these might be missed by L1 speakers. If it is the case that new learners are alert to such structural clues then this in itself could be considered a bright spot, a building block as L2 speakers, so called, come into te reo.

Ko ngaa mea e whai naa i te reo hai reo tuarua, he keri, he keri pea, he puu ranei? He puu pea? kai te whai teenei i a Ruckstuhl (ki Higgins et al ed. 2014: 123-140) e whai ana i a Pullman (1988) maa ki te whakatakoto i teetahi mahere mai i te rangahau moo te taiao. He aha a Otepoti? $\mathrm{E}$ ai ki a Ruckstuhl, he keri pea a Otepoti. He moata kee pea ki te moohio he keri, he puu raanei?

Are second language learners a sink, a pseudo sink or a source following Ruckstuhl (in Higgins et al ed 2014: 123-140) - Or are they a pseudo source? Ruckstuhl develops an ecological model drawing on Pullman (1988), Tittler, Fahrig and Villard (2006), Watkinson and Sutherland (19950 inter alia to provide a model involving a sink, a pseudo sink and a source. A sink is death for a species or to a language and Ruckstuhl floats the idea that Dunedin might be a sink. It may be a pseudo sink though where an apparent death is an actual survival or it may be a source, a way forward or a growth point for te reo.

Kia whai ai taatou i a Ruckstuhl ko te Pouwhakaata Maaori i toona aahua tuatahi he keri pea, i te mea tuarua he puu...pea.

Applying Ruckstuhl's thesis elsewhere Maori Television in its first form looked like a sink, in its second form it seems to be a source and so might we, perhaps, call this a pseudo sink? 
Ko Ruckstuhl, peeraa i a Mamari Stephens (in Higgins et al. ed 2014: 53-85), e paatai ana ia kia whakakahatia te Ture Reo Maaori.

With respect to the state, Ruckstuhl, like Mamari Stephens, discussed later (in Higgins et al. ed 2014: 53-85), recommends a strengthening of the Maori language act. The idea here is that the state should be a home for the language where Maori functions as a civic language.

He iti te rahi rangahau o Ruckstuhl. aa, kai te pai teenei. E koorero ana a Ruckstuhl moo te kaainga, te kura me te kaawanatanga me te uu ki runga o te mea tuatahi. He pai teenei naa te mea ahakoa he iti, he pounamu. Ko te whakaaro ki koonei kia kitea te reo ki roto i te kainga o te kaawanatanga, aa, kia koorerotia te reo ki reira hai reo totika. Moo te rangahau e taea naa e Ruckstuhl, he iti te tirohanga. Ki roto o teenaa ka mahi a Ruckstuhl i te rohe o te kaainga, te kura me te kaawanatanga. Ko te waahi tuatahi ko te kura. Ko te iti o te tirohanga, ka kitea hokitia teenaa i te nuinga o nga rangahau reo Maori pea.

With regard to the actual research that Ruckstuhl does there is a smallness of scale and within this Ruckstuhl works around the familiar territory of home, school and state emphasising the first of these. Studies of Maori language may always have to work with a smallness of scale and managing the reo within a tight compass is the name of the language game in this case. It is a process more suited to the anthropology of a small scale society than the sociology of a mass society.

He mea kaha, he nea ngoikore i te tapatoru e meatia mai e Ruckstuhl. Ko te kura he reo anoo ki reira inaianei (cf ngaa koorero ki te reo iirirangi 2014)? He pai raanei te whakaako i ngaa kaiako? E ai ki a Karetu (ki Higgins et al. 2014:85) kaore kau he ngoikoretanga kee ki te kura teitei, aa, he hapa teenei moo te mahi whakatika taangata hai kaiako. Kua ai ki eetahi 
rangona koorero e arotakengia teenei pea e te Taura Whiri. Ko te Kaawanatanga he mea pai i eetahi waa engari i eetahi kaaore kau. A muri e koorero au moo Stephens i runga o teenei kaupapa. Ko te kaainga, he mea uaua teenaa inahoki e ai ki te tatau o te census he puu taangata i raro i te pakeke tekau maa rima tau.

This triangle of home, school and state has its strengths and weaknesses. There is the suggestion that school language is a language of its own now (cf radio interviews 2014). There is also the matter of teacher training and expertise. Karetu (in Higgins et al. 2014: 85-98) points to the upper school where students are not taught well enough and so the cycle of appropriate candidates for teacher training breaks down. There have been reports of Te Taura Whiri beginning to monitor teaching standards (Te Karere May 2014). Then there is the dependence on state as discussed in the consideration of Stephens. Then there is the fragility of the home environment as seen in the population explosion in the under fifteens in the census.

Peenaa i a Karetu kaaore a Ruckstuhl e koorero ana moo te reo irirangi. Naa te aha teenei? Kaaore hoki a Ruchstuhl e koorero ana moo te ipurangi me te pouwhakaata engari ko te ao paaho he mea tuawhaa kia aapitihia ki ngaa mea e toru; te kaainga, te kura me te kaawanatanga.

Both Karetu and Ruckstuhl stay clear of radio as an influence. In Karetu's case this sems to be partly a matter of his experience with Te Mangai Paho. In Ruckstuhl's case she finds that radio is not a help with Maori in Dunedin. A point worth exploring though might be whether radio could be a help in learning te reo. If the radio is not there as a resource in Dunedin why not? It is of course on the internet and if parents are not using it on the net then, again, why not? Ruckstuhl does not talk much about the net and or about Maori Television and this seems odd as in addition to the three 
points of whanau, kura and kawanatanga, family, school and state media might be added as a fourth.

Ko te mea tuarima pea ko te iwi. He rawe kee nga koorero naa Jeremy McLeod, Pakake Winiata, Hana O'Regan, Mike Ross me Ngapoo Wehi ki Te Hua o te Reo Maori (2014) moo te tuu o te iwi moo te reo me te whakahaapairanga o te reo ki te pai o te iwi.

Then there is a fifth point; iwi. In Te hua o te reo Maori (2014) there are very good contributions by Jeremy McLeod and Pakake Winiata as well as Hana O'Regan about the role of iwi in language development as well as the development of language to an iwi standard.

Ko te mea tuaono ko te ao tapere. Ko te Kapa Haka me te kanikani. Ka koorero a Ruckstuhl moo kapa haka hai waahi karawhiti moo ngaa whanau (op cit. 2014:123). Ko te kanikani tae hoki ki te kapa haka, he mea paingia rawatia e te hapori i te whutupooro me te neti pooro ( $\mathrm{cf}$ danz website). He waahi pai teenei moo te ako i te reo. E ai ki a Bonbright me Bradley (2013) he rahi ngaa pai moo te hinengaro i te kanikani tae hoki ki te akoako. Ka tae $\mathrm{i}$ a taatou te ako pai i te reo i a taatou e kanikani ana.

I would point to a sixth area and that is performance especially kapa haka and creative dance. In her study of language learning Ruckstuhl talks about kapa haka as a gathering point for whanau (op cit. 2014:123). Dance, including Kapa Haka is more popular than rugby and netball in New Zealand (cf danz website) and has to be seen as a learning site for language and other things. In Evidence (Bonbright and Bradley 2013) there is a strong research case for neuroscientific evidence for learning benefits from dance. Are we using dance including kapa haka well in language learning generally and specifically with te reo in Aotearoa? 
He mea pai, he mea kino hoki i eenei mea. Hai tauira ki te ao paaho e kitea nei te toro o Te Panekiritanga o te reo ki, me kii, Te Karere inahoki e tika ana kia tautokongia te koorero e ngaa tuhinga ki raro. Engari raa e kitea hokitia ki Te Karere te tino pai o nga kaikoorero mai i te Paremata me te hari o eenaa. Ki ngaa kura, ko te raru kaaore e moohiotia

te reo kura ki waho o teenaa, engari he pai kee eetahi mea ki roo kura.

In each of the areas there are positive and negative possibilities. For example in the media we have the silo effect of Te Panekiri o te reo in, say, Te Karere where the language is indecipherable to many except via subtitles. But we have the positive effect of Maori spoken by parliamentarians and relayed strikingly well in the media, especially on Te Karere. In the schools we have the silo effect where the language used for mathematics and science creates its own walls and may not be understood on the street outside the classroom. And yet there are extremely positive features about schools as places to learn and develop the language through speech competitions and the like.

I te whanau, ko te mea uaua pea ko te iti o ngaa rawa. Ko te puu taangata o nga mea i raro o te pakeke tekaumaarima e koorerongia naa ki te Tatauranga Taangata (2014) he taumaha anoo teenaa. I te Kaawanatanga ko te raru raru ka nui te tautoko moo te reo i eetahi waa engari he iti pea i eetahi anoo waa. Ka kitea teena $i$ te mahi naa Stephens, aa, i te tauira o Koro Wetere i meatia ki raro, ka maheretia, ka puta noa raanei ngaa tauira peenaa.

In the case of the family the primary concern would be lack of physical resources and the pressures of a population explosion as suggested in the recent census (2014) whereby the population under fifteen is set to increase dramatically. In the case of another important area, the state, the tap can be turned on or off as shown in the work of Stephens. As 
suggested below, this, in the case of Koro Wetere and the Standing Order, can be by accident or design.

Kei te haere te iwi i nga pakitara o ngaa rangatira? He raru teeenei moo ngaa mea $\mathrm{i}$ haramai ai $\mathrm{i}$ te ao iwi ki te ao tari kaawanatanga? A muri e koorerotia nga whakaaro o Iritana Tawhiwhirangi (ki Higgins et al. 2014: 33-52). Kei te koorero ia moo te nukunuku o ngaa taangata $\mathrm{i}$ roto $\mathrm{o}$ te Taahuhu Matauranga i eetahi waahi hoki ki te Kaawanatanga. Kai te whai kanohi, mahere ranei ia?

Do iwi proceed on the shoulders of specific leaders and is this a problem for people coming from an iwi context to a context of governmental bureaucracy?? Later the thoughts of Iritana Tawhiwhirangi (in Higgins et al. 2014: 33-52) are discussed. She is talking about the shifting of people in government and how frustrating that is to her. Is she chasing faces, looking for a person to go with a statement or policy?

He keri, he puu te iwi moo te reo? Teeraa pea ko teaahua he puu engari ki te whakamutunga o te raa he keri. He aha te aha ki piki ai te iwi, kia noho ai hoki ki teetahi reanga teitei moo teetahi waa engari ka taka i teetahi anoo waa? He aaha te aha kia noho ai te iwi ki runga i te kaha o teetahi rangatira, roopu rangatira raanei? Kia whakaarongia te tauira o nga Tekau maa Rua me Ngaa Poukai, he pai kee enei hui i te nuinga o te waa engari he patai anoo ki reira moo te reo $i$ eetahi waa.

In the case of the iwi the question might be put as to whether the iwi are sinks, sources or pseudo sinks as far as the reo is concerned. Or are they pseudo sources where the iwi looks promising as a source but turns out not to be. What happens when the iwi peaks and plateaus and then declines as far as the reo is concerned; where there is dependence on the drive of a leader or group of leaders? Even where there is a high degree of institutionalisation of te reo in, say, the Bay of Plenty with, say, Ringatu Twelfths and the round of hui 
independent of leaders or the coming and going of government, things can be uneven. 


\section{Te rangatiratanga o te reo Language leadership and direction}

He koi ke te whakawhiti naa Timoti Karetu ki te whakaaro kia hoki mai ai te rangatiratanga moo te reo ki ngaa iwi. E ai ki ngaa ripoata he koretake ngaa iwi i ngaa waa o mua, aa, he aha te pai o teenei (Karetu, Waatea 14,7.14)?

The reaction of Timoti Karetu to the idea that iwi will have more of a say in Te Reo in the Te Maataawai arrangement is striking. Karetu is quoted as saying that the iwi have been ineffective in the past and asking why they should be given the chance now (Karetu, Waatea 14,7.14)?

Kua whai au i te ao tapere $\mathrm{i}$ eetahi waahi. He pai te kapa haka moo te reo (Cleave 2009, 20014)? Ko te kapa haka, he puu, he keri, he aahua noa o eenei (cf Ruckstuhl 2014) moo te reo?

In the case of performance there is a lot to be considered and this is extensively treated in Cleave 2014 where the writing of Matthews and Karetu and Mazer are considered. In Starting Points (Cleave 2009) the work of Rahera Mahuta Kaai is discussed. Is Kapa Haka a sink, a source, a pseudo sink or a pseudo source as far as te Reo is concerned (cf Ruckstuhl 2014)?

Ko teetahi mea, te mea tuawhitu pea, ko ngaa kaumatua. Ko taaku mahi rangahau moo te roopu kaumatua ki Rangitaane Paa, Papaioea, ka kitea ki reira nga rawa e pirangitia ana e raatou. Ko nga '-tanga' katoa peenaa $i$ te Maaoritanga, te Raukawatanga me eetahi atu tae noa ki te reo tonu. He mea kaha rawa eenei taangata.

In Starting Points I emphasise the role of the Kaumatua and here this might be suggested as a seventh possibility for language development. This is a possible 'arc' area for the reo. As a Kaumatua programme has developed at Rangitaane Pa, 
Palmerston North I have been doing focus group work for Kia Ora FM with this group. That involved asking them about their attitudes to Te Reo and how it might best be used on the radio. They are very passionate with respect to values they see as carried along in the reo. All the -tangas via, perhaps the Wananga o Raukawa, are in their responses; Maoritanga, Raukawatanga etc. It seems an obvious area to develop and extend a minority language, through the elders. But the political and social transformation of the situation of kaumatua and kuia in the Central North Island from Palmerston North to Hamilton has been striking in the last few years and there is now a growing and well organised set of people with a strong desire to learn or extend the reo and the time and resources to do so.

Naa te kaha o te whakaaro o ngaa kaumatua moo te reo ka huri anoo au ki ngaa whakakoohatutanga me te whakamaharatanga, He hurihanga teenei ki te whakaaro ka uu rawa te reo i te taha maaui. aa, i ai ki te koorero moo Zepa $\mathrm{i}$ te hui o Te Maangai Paho ki Rangitaane Paa $\mathrm{i}$ te waa o neheraa, aa, ki a au i te waa o te whakakoohatutanga me te whakamaharatanga. Ahakoa teenaa, he mea nuku, he mea ora, he mea hikohiko i eetahi waa te reo moo eenei kaumatua. Kaaore kau he waahi mate, he keri raanei.

It was by virtue of the force of the interest from the kaumatua in the values of te reo that I first began to think about what I later called classicisation and what, perhaps, Mazer and Foote think of as memorialisation. And this went with my reading of Zepa theory that Te Reo was stuck, to some extent, on the Left, in the past, and, to use my terms, in a field of memory, in a form of classicisation. But it is a living area, a language zone crackling with energy for the kaumatua and certainly not a dead zone or a sink.

Anoo, i 2013 peenaa i ngaa tau i mahue noa moo eetahi take moo te reo, he itiiti kee ngaa whakawhitiwhiti koorero i a au e paaho anoo moo eenei take $i$ te reo irirangi. 
Again in 2013 as in earlier years with other topics concerning Te Reo there was little or no response as I talked about these issues on the radio.

I te maarama o Maehe 2014 ka whakataa au i te pepa ki tekaharoa.com, Memory Body and Dance, a literature review, aa, he paku koorero ki reira moo Zepa Theory. I teenaa pepa ka whakaorite au i teenaa ki ngaa whakaaro o SharonMazer me Keneth Foote me aa raaua mahi moo te whakamaharatanga. Ka maatau hoki au ki te whakawhaanui i te kupenga koorero (Cleave 2014).

In March 2014 tekaharoa.com published Memory Body and Dance, a literature review that talked briefly about Zepa theory. In that paper I compared it to the positions of Sharon Mazer and Kenneth Foote and their work on memorialisation and tried to situate these linguistic discussion in a wider discourse (Cleave 2014).

Kai te whakaaro au moo eetahi atu maatau ki te kite i ngaa whakaaro moo te whakahounga $i$ te reo $i$ roo tonu $i$ teetahi waahi whaanui, aa, ki te paatai moo te pai o teenaa. He whaaiti rawa te rangahau aa reo, te reo me te hapori hoki, aa ki Aotearoa, kaore he tumu? Ko te tuunga o te reo, e tika ana kia koorerohia teenaa $\mathrm{i}$ te taha o eetahi taonga kia moohiotia te rawa o te reo, aa, he pai kee te tirohanga whaanui kia moohiotia ai ngaa mea tino pai.

I wonder how many other attempts there have been to situate ideas of language revitalisation in a wider field of discourse and how useful that might be. Is the field of linguistics and sociolinguistics, too narrow and in New Zealand and with respect to Te Reo Maori is it without bearings? The way people value language sits with the way they value other things and it may be that a wide angle assessment of priorities and relativities would be useful. 
He whaaiti rawa te tirohanga o nga mea e aarahi ana $i$ te reo? I te mea tuatahi ka taea te aarahi i te reo? He mea e tika ana kia tohetohetia teenaa pea engari ki Aotearoa he pono rawa, he mahi nui hoki ki te whakahou i te reo. Ko te paatai he mea awhina, he mea aarairai raanei teenaa i te haere o te reo?

Along with the above the idea that language direction might be happening from too tight a control system occurs. Is it possible to direct the way a language develops in the first place? While this is might be debatable the facts are that in New Zealand there is a determined belief and effort to revitalize the language. The question is how is that helping or hindering the actual progress of te reo?

Meenaa kai a taatou he rangatiratanga o teetahi roopu moo te reo e tika ana kia whakaaraongia nga tuhinga na eetahi kairangahau tae rawa atu ki a Pareto kia korerongia te whakaaro pea e tuu ake tena rangatiratanga ki teetahi anoo. Atu i teenaa e tika ana hoki kia whakaarongia nga mea e kiia nei, ko 'co-governance' me 'co-management' (cf Putnam 1977). E tika ana pea kia panui anootia te koorero mo Timoti Karetu me Trevor Mallard o te Torangapuu Reipa, Timoti me Maurice Williamson o Te Torangapuu Nahinara hoki (Karetu ki Higgins et al. ed. 2014: 85-98).

If we have a situation where there is control by an elite and in New Zealand it is difficult to see how this might not be the case then there are distinctions of elite and counter elite to be drawn from theorists going as far back as Pareto. Then there might be co-governance and co-management by elites (cf Putnam 1977). In this context we might read again Karetu's account of his relationship with say, Trevor Mallard from the Labour Party and Maurice Williamson from the National Party; Karetu the Maori Language bureaucrat and Mallard and Williamson the Ministers of Government (Karetu in Higgins et al. ed. 2014: 85-98). 
E tika ana hoki pea kia tirohia anotia te hoohaa o Tawhiwhirangi me Stephens me nga mahi o tena tari kaawanatanga teena raanei. Ki tua o tena kia hoki anoo ai ki a Karetu me taana moo te kore niho o te Ture Reo Maaori. Kia mahi pai ai te ture e tika ana kia whakatinanatia nga mahere, aa, kia taea te peenaa e tika ana maa nga ropu rangatira e mahi tahi ai.

We could also look at Tawhiwhirangi's frustration and that of Stephens with government processes. And then back to Karetu with the need for Te Ture Reo Maori to work, to have teeth. For that to happen there needs to be execution of policy and in turn for that to happen elites and counter elites need to work in harmony.

Kia hoki ai au ki te Maehe me te Aaperira o 2014 ka koorero au ki eetahi taangata moo te Rautaki Reo Maaori. Ka paanui hoki au i eetahi ripoata mai i teenaa kaituhi, teenaa raanei moo ngaa whakaaro, me kii, o Koro Wetere me Timoti Karetu (cf Te Kaea Aperira 2014). I teenei wa he koi kee te whakaaro i te hapori moo te kaupapa nei. He kaha rawa hoki te whakaaro.

As mentioned earlier, in March and April of 2014 I interviewed various people about Te Rautaki Reo Maori. I also read reports from journalists on the views of, say, Koro Wetere, an earlier Minister of Maori Affairs and Timoti Karetu (cf Te Kaea April 2014). This time around there was a buzz about the issue and people were interested. There was also a passion from the people interviewed that was striking.

Kaaore au e koorero tika tonu moo nga koorero i te reo irirangi engari i puta ake eetahi paatai, etahi take kia whaia ai.

Without quoting directly from the interviews on the radio several questions emerged, several issues to be pursued. 
Ko ngaa kupu 'silo' me 'enclave', he rahi kee ngaa putahanga o eenei kupu i ngaa koorero ki runga reo irirangi. Ka puea ake nei eetahi paatai. He silo, he enclave anoo a Aotearoa kia whakaarongia te iti o Aotearoa? He peenei tonu taatou ake, ake, ake?

The words 'silo' and 'enclave' are used fairly extensively in the interviews. Several questions arise. Is New Zealand itself a silo or an enclave given that with Te Reo Maori in New Zealand we are talking about a fairly small population of some 4-5 million maximum number of speakers, Maori and non. Are we ever doomed to be an enclave or a silo because of our small scale?

He oorite nga kupu 'silo' me 'enclave' ki te kupu 'ghetto' i nga hinengaro o eetahi? Kia iti rawa atu te hapori koorero i ngaa taangata e rapu ana $i$ o raatou anoo naa aahua he awhina te whakaaro peenaa? He mataku rawa moo te reo raanei e ngoingoi mai ki te hinengaro?

When people use the words silo or enclave do they really mean ghetto? In the minority language situation where people are searching, sometimes desperately for identity, does such an attitude help? Or is there a kind of language paranoia that creeps in here.

Ko te Rautaki Reo Maori, e karanga atu mo te whakahokihanga o te reo ki te iwi. He karanga tawhito teenei. Hei tauira i te Ripoata Workman kei reira teenei e whai nei;

More direct participation by iwi in this process was also strongly supported.

Te Rautaki Reo Maori calls for a taking back of the reo to iwi. This is an old call. For example, in the Workman Report of 1998 there is the following;

More direct participation by iwi in this process was also strongly supported. 
He rahi nga rawa o ngaa iwi?

Are the iwi sufficiently resourced?

Kei reira te reo i ngaa waahi katoa?

Is the reo there in all cases?

He mea whakawhaiti rawa te mahere nei?

Does this strategy itself have a constricting effect?

Ko te whakahokihanga ki te iwi, he mea whakakahatia teenei e ngaa tono Waitangi naa ngaa iwi kia whakarerekeerawatia te reo koorero o tena rohe, teenaa? Ko te whakaaro o te reo i koonei, he whakaaro tono. He taaonga te reo. He aha te aronga o teenei? Ko te reo me te aahua o te iwi, he mea nohotahi ake, ake. ake enei?

Has the matter of taking things back to the iwi been reinforced by treaty claims by iwi so that, in some cases, what was a set of dialectal differences has been made over into something that it is not, a distinctly different language? Language in this way becomes an asset that can be claimed. The relation of iwi identity to language is important but how far should it be taken?

Ka raarangi teenei ki eetahi tuhinga naaku moo te nako wairua (Cleave 2007) me te karanga atu ki te moohiotanga o te iwi. Kai te haere tonu teenei ki 2014, aa, e kitea teenei i eetahi rangahau naa Ruakere Hond $(21.5,14)$. Kai te koorero a Hond moo te pai o te mahi aa hapori me te ngoikore o te aronga ki te tangata takitahi.

This lines up with earlier writing on the mystic core (Cleave 2007) and an appeal to folk wisdom. This carries on to 2014 with comments about recent research by Ruakere Hond (21.5.14). Hond seems to be calling for less emphasis on individual instruction and more on community initiatives. 
Engari ko te reo o te iwi he tohu o te pai raanei o te koorero atu i te iwi? E tika ana kia haangai te reo koorero o te iwi hai tohu moo te reo koorero pai o ngaa taangata e haere noa, koorero noa? He pai rawa raanei kia tuu pai ai te koorero e hari aronga tika rawa atu i eetahi koorero ahakoa noo whea nga kupu, te mita, te aha raanei o te koorero?

Should the language of the iwi be taken to be a benchmark for the market?. The market might be defined as on air or in the classroom or wherever the language is spoken. What seems to happen is that the language spoken in the market is often criticised in terms of the language spoken by iwi, positive or negative as that criticism might be. This use of the language of iwi as a value point, a benchmark of quality is significant; is it helpful for language development? Or is it better to take what works, what functions best in communication as the benchmark whether this is from the iwi or from anywhere else?

Ko te take whaanui rawa ko nga rawa. Kai te moohio taatou i te Tatauranga (2014) moo te tipu o nga mea i raro i te pakeke tekau ma rima tau. Kai te moohio hoki taatou kai ngaa taaone te nuinga o ngaa taangata, kaaorew noo te tuawhenua, no reira kaaore noo ngaa whenua iwi. Ki tua o teenaa ka mea mai te Tatauranga kai te iti haere te tatau o ngaa mea Maori ki ngaa Whare Waananga. Kai te aapiti ake eenei mea kia uaua rawa te tuari o re reo ki eetahi.

The broader issue is to do with resources. The latest census in 2014 tells us that there is population growth below the age of fifteen. It also tells us that the population is urban and not rural so mostly not in or near iwi areas. And it tells that the number of Maori in tertiaries is in decline. These things add up to make the delivery of iwi language difficult for many. 
Ka kitea te uu o teenei i te whakapae naa Timoti Karetu moo te ngoikore o te mahi ako ki te reanga teitei o nga kura tuarua (Karetu ki a Higgins maa 2014). Kia taea te tono kia akona te reo i nga kura katoa o Aotearoa he uaua pea ki te whai tangata ako ai.

This analysis seems to tighten when a suggestion made by Timoti Karetu is considered that in his experience there is a real concern about the teaching and learning of Maori pupils in the upper secondary school. (Karetu in Higgins 2014) This is important so that when in July 2014 there is a suggestion that Labour, if elected will make Maori (NZ Herald July 14 2014) compulsory in schools the next question is who will teach it and to what level?

E tika ana pea kia koorerotia anootia te aahua o te rangatiratanga, aa, kia whakaarongia eetahi mahi rangahau (Putnam 1977). He uaua kee pea te whakatinanatanga o ngaa tono mai i te rangatiratanga ki te nuku o te whenua. Hai tauira kia taea teetahi mahi-aa-reo ki te Panekiritanga o te Reo, ka haria atu teenaa e ngaa taangata i haere ai ki reira, aa, ka haere tonu pea ki te Pouwhakaata Maaori engari kaaore e haria ki ngaa kaikoorero katoa o te motu.

This might be widened to look again at elite theory and the development studies literature (Putnam 1977). When decolonisation happens an elite is often left to lead a country. The directions given by that elite depend on the capacity of those in their implementation. So that when the Maori Language Commissioner wants to transmit something that might work for people in Te Panekiritanga o te Reo, it might also work for graduates of that programme in Maori Television but it might not work elsewhere.

I te mahere ki te whakatinanatanga ka maahakiruatia te mahi i eetahi waa. Kai te koorero a Timoti Karety moo teetahi mahere noona kia tiakina te reo engari ka pakarutia te mahere inahoki ko Kirikiriroa te waahi pai ki a Karetu engari ko 
Otepoti te waahi pai ki a Trevor Mallard, te Minita i teenaa wa (Karetu 2014:94).

In the execution of a suggestion from the elite by people further down the chain of action if Te Taura Whiri want something to happen in Teacher Education and the supply of Maori speakers from the schools is insufficient for this to happen as a result of low supply via the senior secondary school then the implementation of language policy may be thwarted. Sometimes the chain of execution is snarled in cross purpose. Timoti Karetu describes wanting a training situation, a situation where te reo was to be protected, in Hamilton while Trevor Mallard the Minister of Education at the time wanted it to be, if anywhere, in Dunedin (Karetu 2014: 94).

Kei te hiikoi tahi Te Mangai Paho me te Taura Whiri o te Reo? Kia paanuitia taa Karetu (Karetu 2014: 92) ka rongohia te hoohaa moo Te Magai Paaho.

Karetu also says that he does not know about Maori radio, these days at least, and there seems to be a frustration in his writing about Te Mangai Paho (Karetu 2014:92) that is even stronger than his frustration with other parts of government.

Ko teenaa pea teetahi tauira o nga rangatira kaaore e hiikoi tahi ana i eeetahi moo te whakatipu o te reo. He mea whaitia ai e Te Taura Whiri, teeraa pea e kore e taea teenaa ki eetahi waahi peenaa $i$ te reo irirangi, i runga marae raanei. Naa teenaa pea e whakahoki koorero ana a Karetu moo te whakapae o gobbledegook i te haua o te hiikoi.

This might in fact show the existence of an elite out of touch or, at least, out of step with language development. A change sought by Te Taura Whiri might not be executed in other areas, say Maori radio or on the marae and so we have Karetu defending the charge of gobbledegook (2014:96) when the business if being out of step is revealed in an extreme way. 
Kia whakaarongia a Karetu me te whakapae o gobbledegook e kitea pea te whakauruhanga o teetahi reo, he reo anoo. He uaua teenei i te mahi whakamau anoo, whakaora anoo o tre teo e haere ana. Hai tauira, te mahi e ataea naa e nga iwi wheenaa i taa Ngai Tahu mo Too raatou reo. Itiiti kee ngaa taangata e koorero ana i nga reo aa iwi wheenei, aa, kia aapitihia ngaaa ahuaranga o Te Panekiritanga o te Reo ka whakatuungia he reo anoo $\mathrm{i}$ runga, $\mathrm{i}$ te taha raanei o teetahi reo anoo...

Regarding Karetu and gobbledegook we may have the bringing into being of another language, he reo ano. This is complicated as the retrieval process goes on so that, for example the retrieval/ revitalisation- how these two terms are defined is important- of the Ngai Tahu and other dialects often goes hand in hand with the Panekiritanga o te Reo approach (O'Regan 2014:117). There is the danger of an almost infinite regression where there is another language and then another with one helping to make another yet more obscure.

Akakoa te reo ko te kaikoorero te tangata e whakahaere ana $\mathrm{i}$ te reo kaaore te tangata ki te tari, te kaimahere raanei. Naa teenaa e tika ana kia whaia ai te whakatipuranga, the whakarerekeetanga raanei ki te reo koorero ahakoa te rongo ki te taaringa.

With any language the speaker is in charge,

not the bureaucrat or the theorist. The user rules and the general rule of use it or lose it applies. This means that an organic approach where growth points in the language no matter how ugly they may sound to a purist may need to be encouraged as much as they are discouraged at least.

Hai tauira, ki te reo irirangi e tika ana kia whaia te mea ki te ringa, kia haangaia teenaa i te waa tonu. Kia moohiotia te mea e tika ana kia meatia. Kaaore kau raa teenei he mea peenaa i te reo Romana, Huurae raanei, he reo karakia, he reo 
kawa me kii e whakaoratia ana e teetahi hapori kaikarakia nui. I eenaa tauira he raahi pea te waa whakatika koorero.

On the radio for example the approach has to be organic, taking what is to hand and using it in the moment. Anything goes so long as it makes sense. There is not the luxury of sacramental language use as with prayers in Latin or Hebrew, languages that were kept in a more or less pristine state for centuries through a large community of prayer givers. In those cases there is usually time to make studied corrections.

Kia whakatakotongia te paatai ki ngaa rangatira o te reo; kai te whai koutou i te reo whakatipu, te reo karakia raanei, he aha te aha? He aha te whakaraarangi o ngaa hiikoitanga whakahaapai i te reo?

The question that might be asked of an elite of language bureaucrats might be whether they are pursuing a sacramental language or an organic one. If both are being pursued what are the priorities?

He hokihanga ki teetahi ao koohatu o te hinengaro, he hiikoi whakamua raanei eenei mahi reo?

Coming back to the emphasis on iwi dialects, is this a return to an idea of an earlier time or a step forward? Are these languages, these dialects being retrieved from the past and preserved, curated and made sacramental or are they being placed in the present and poised to develop?

Anoo, he aha te whakaraarangi o ngaa mahere reo me eetahi mahere i, me kii, te ao toorangapu, aa, he aha te hua o ngaa whakaraarangitanga peenei. Hai tauira, kai tec whai te mahere o Te Maataawai i nga whakatau Tiriti i te whakakaha o nga iwi. Ko te mahi whakatipu reo me te mahi whakakaha, e haere tahi ana eenei, he hua i te hononga? 
Again, what do language strategies in this country line up with outside of language and in, say, the political sphere and what effect might such an alignment have? Does, for example Te Maataawai, the proposed new department for Maori language align language development with Treaty settlements so that iwi are resourced more than other groups in a process of apparently devolving more power to iwi? Will this be a strong alignment, a link that arcs the spark and delivers a powerful result or will it be a fizzer?

Ko te Taura Whiri, he enclave, he silo raanei teenei? He waka moo te rangatiratanga raanei? Mai i te tau 1987 kua tuu Te Taura Whiri i teetahi waahi motuhake, kaaore ki mua, ki muri raanei o eetahi roopu peenaa i Te Maangai Paaho moo te rangatiratanga o te reo. I Te Maataawai e kitea nei te whakaurunga o Te Taura Whiri ki raro o te maru o teenei whare hou.

Is Te Taura Whiri itself an enclave or a silo? Or is it a leadership vehicle? Te Taura Whiri has been in a space of its own since its inception after 1987, neither ahead of or behind other entities such as Te Mangai Paho in terms of leadership and control in terms of Te Reo. With Te Maataawai we have an incorporation of Te Taura Whiri proposed into this new entity.

Naa Koro Wetere he whakahokihanga ki teenei (Te Kaea April 2014). Ko taana, kia aarahi ai Te Taura Whiri i te reo me ngaa mea e pa ana.

A response from Koro Wetere to this suggestion (Te Kaea April 2014) is that Te Taura Whiri should lead Te Reo and other entities ought to be found within it.

I roo hoki i teenaa ripoata ko te whakapae naa Timoti Karetu ki Te Maataawai moo eetahi mea wheenaa i aa Wetere. 
The same report intimated that Timoti Karetu, himself a former head of Te Taura Whiri opposed Te Matawai for the same or similar reasons.

He mea awhina ngaa mea peenaa i a Te Panekiritanga i Te Reo moo te toro whaanui o te reo, ka whakatuu raanei $\mathrm{i}$ teetahi roopu iti e whai ana i teetahi reo motuhake?

Are exercises like Te Panekiritanga o te reo helpful in the wider dissemination of the language or do they create a small band of speakers with an almost secret vocabulary and style? Do exercises like Te Panekiritanga o Te Reo, amongst other examples of language societies Mensa groups and the like, comprise a Lodge, a Language Lodge? With initiates, novices, masters and the Truth inside and ingrates. shysters and pretenders outside along with Falsehood?

Kia whaatuungia he roopu whakahaere tari peenaa i te Te Taura Whiri kia taea ai ngaa mea moo te reo e whai noa raa ngaa roopu kaikoorero wheenaa i te Panekiritanga o te Reo?

Once a bureaucratic elite in the form of Te Taura Whiri is set up to 'deal with' the language does this inevitably mean the development of speaker elites like Te Panekiritanga o Te reo which in turn leads to an elite of broadcasters speaking an elitist language.

Kei te pai teenei meenaa he 'subtitles' peenaa i eenaa ki te Pouwhakaaata engari kaaore i te pai ki waho o teenaa?

Does this approach work where there are subtitles, as on some news broadcasts on television but not elsewhere?

E tika ana pea kia rangahaungia ngaa roopu rangatira, te whakatuu o nga roopu rangatira, te tuari o eenei me te kaha, te mana hoki o eenei. Kua whakatakotongia te whakapae he iti pea te kaha me te mana o eenei roopu i te tauira o te whakaako kaiako me ngaa mea e whaia nei e nga roopu 
rangatira ki reira. Ko teetahi mea ko te toro me te tuari o te roopu rangatira o te reo. Ko te iwi i mau rawa ai i te reo ko Tuuhoe pea engari kei diaspora raatou (Mataamua me Temara 2010). Te noho tahi o nga mea matatau ki re reo ko teenaa teetahi o ngaa moemoea o Hoani Rangihau i a ia e whakatuu ana i ngaa Ahurei Tuuhoe. Ko te paatai inaaianei ko teenei pea; he pai rawa kia noho tahi ai ngaa mea matatau ki te reo $\mathrm{i}$ ngaa waa katoa, i teetahi wa roa rawa i te ahurei pea, koorero ai ki waenganui tonu i a raatou i te reo.

One thought to follow up with regard to research may be to do with elite formation and their dispersal as well as their actual power. It has been suggested that the actual power of the elite involved in language retrieval and revitalisation is limited and the example given has been of teacher training not being up to the standard required by language leaders, But there is also the question of elite dispersal as far as the iwi are concerned. The iwi with the most retention of the reo is possibly the Tuhoe and they are effectively in diaspora (Temara and Mataamua 2010). Keeping an elite of language leaders together and in close proximity to the rest of the iwi was a challenge recognised early by John Rangihau with his Ahurei Tuhoe begun in the mid 1970s. The question might now be put as to whether it might be better to have these speakers together all the time or for a period at least longer than the festival.

Ko teetahi o ngaa hui o ngaa roopu rangatira o te reo ko te reo e koorerongia i Te Panekiri o te reo me Te Karere. He reo matataungia naa e eenaa e koorero ana i teenaka reo. Ko te whakapae e puta, ka here teenei reo ki hea? Ko teenei pea he tauira o te roopu rangatira e mau ana i teetahi mana nui rawa moo te mahi inahoki kua whakarerekeetia te reo hai mea raawaho ki ngaa kaiwhakarongo. Ko te rongoa moo teenei ko te whakamoohio o te roopu rangatira i nga hapa mo eenei moumou mahi me nga mea pai hoki. 
Returning to elite formation the development of $\mathrm{Te}$ Panekiritanga o te reo and the emergence of news shows like Te Karere has encouraged an in house form of Te Reo and there are now challenges regarding the spread and dispersal of the language spoken. This might be seen as an example where the elite has too much power so changing the language of speakers in ways that listeners do not understand. The antidote might be in how the elite is informed, how or whether they know that the things they can and do implement are effective and not counterproductive.

He waa uaua teenei mo ngaa roopu rangatira o te reo Maori inahoki i te tatauranga taangata i mahue noa (Census 2014) ka iti haere ngaa mea Maori ki nga whare waananga.

All of this is in a general context of development where the elite, especially the educational elite- the 2014 census suggests that the number of Maori in tertiaries is declining- is pressured and challenged generally speaking.

E tika ana hoki kia aata whakaarongia ngaa mahere me ngaa tauira e whaingia naa e ngaa roopu rangatira o te reo, aa, ka koorerongia eenei moumou mea i ngaa wharangi e whai nei.

There is also a need to look at elites and the theories they espouse in language development and revitalisation and this is discussed below. 


\section{Identity and Property}

the investment into the language for Maori is more than just a language of communication; it is a fundamental part of our identity as Maori

Te Mangai Paho Cluster Group paper 2013

Ko ngaa teihana reo Maaori me ngaa aahua kua whakatuu ai i Te Maangai Paaho, he 'silo', he 'enclave' ranei? Meenaa ka peenaa ko te puutake he aawangawanga moo te paatai noo wai kee raa te reo? Ko te Pouwhakaata Maaori he huarahi atu $i$ te waahi nei? He paatai i koonei moo te aahua o te reo?

Are Maori radio stations and the systems set in place by $\mathrm{Te}$ Mangai Paho a silo or an enclave? If that is the case is the reason that people are anxious about ownership and identity? Is Maori television, given the positive viewing figures, one way out of a silo? If that is the case are there questions about the identity and ownership of the language?

Kei te nuku eenei mea i ngaa silos iti ki ngaa aahua nui rawa peenaa i ngaa karetao o Ruuhia teetahi i roo teetahi. Ko te iwi he silo iti, te hapori Maori he mea nui rawa ko te marea o Aotearoa, he mea nui rawa anoo. Engari ko te paatai he pai raanei eenei waahi moo te ako me te mau i te reo? Ko te Pouwhakaata Maaori e toro atu ki eenei waahi engari kai te ngaro te nako me te wairua o te reo i teenaa?

Do these things move from smaller silos to bigger ones a bit like Russian dolls, one inside the other? The iwi is a small silo, the Maori community is a bigger silo and New Zealand society at large is bigger again but are any of these silos any good at retaining and developing a specific language? Maori Television might reach across these areas but is it losing vital aspects of Te Reo as it does so?

I ngaa waa peenei ka tuu ake ngaa Roopu Reo. E ai ki te koorero kua huihui eetahi roia ki te ako i te reo. He mea pai 
hai toona anoo waa, peeraa hoki raa te rangatiratanga o te roopu me te toro atu ki te hapori whaanui e koorero ana $\mathrm{i}$ te reo. Ka haangai te koorero moo ngaa silos ki runga ki eetahi aahua o teenei.

In a minority language situation the Language Society usually appears. There are reports of knots of lawyers getting together to learn Maori. All this is potentially to the good as is the management of the society and its interaction with the wider language community. The silo or enclave critique set out above obviously applies and silo management is necessary; as the language tends to the restricted and esoteric or confined, as it were, to a political frame or a cultural cage (Smith 1997) so it needs to be taken out for a walk in the sun of the community.

Teeraa pea ko te ao katoa, he silo, he raarangi pea o ngaa silos. Teeraa pea e tika ana kia aata waanangahia te kupu 'silo'.

Perhaps the world is just one big language silo or series of. Perhaps we need to look long and hard at the word 'silo'.

Naa te aha kaaore he whakaaro nui ki te Rautaki Reo Maaori moo te ao paaho Maaori? Kei hea hoki nga kura Maaori i ngaa Whare Wananga i te Rautaki Reo Maaori?

Why is there not a great deal of attention in Te Rautaki Reo Maori on Maori broadcasting? Where are schools of Maori Studies in Universities, Wananga and Polytechnics in Te Rautaki Reo Maori?

E tika ana maa taatou e mau i teetahi nako wairua moo te reo (Cleave 2009)?. Kia koorero ai taatou moo te reo me oona aahuatanga e kore e kore e uru mai eetahi aahua. Ko taa Flavell, he reo wairua te reo Maori ki roo Paremata (Flavell 2014: 99-108) Ko ngaa tikanga, he mea e kitea naa i te reo. he mea hiikoi tahi eenei, e tuu noa iho raanei raa te reo? Ko te 
Rautaki Reo Maori teetahi mea e paangia rawa e te mahere Sapir Whorf (1956)?

Can we afford what I have elsewhere (Cleave 2009) called a mystic core to the language. There is an investment of meaning that goes on when you talk about te reo me ona ahuatanga, the language and its aspects. The article by Flavell in Higgins et alia (2014) argues that te reo has a spiritual significance in Parliament and talks about he reo wairua. Culture is a thing seen through language. Is it language itself? Has a version of the Sapir-Whorf hypothesis (1956) run riot through strategies to do with language retention?

Ko te pouwhakaata Maaori, he mea pai ki te hapori, he mahi pai hoki moo te reo, kaaore teenei e whai ana i te kapa haka, te hui raanei. Ko Te Reo he waka ki te taha e hari ana $\mathrm{i}$ nga mea tikanga.

Maori TV, arguably- at least from the point of view of popularity- the most successful language revitalisation and retention venture that we have is not hui focussed and nor is it Kapa Haka focussed. Te Reo, the television channel, is or may be and, in this case, the 'cultural stuff' has been farmed out to an outpost station.

Kia whakaarongia eetahi o ngaa koorero o mua noa, ko te whakaaro teihana rua peenaa $i$ te mahere Zepa me te Pouwhakaata Maori ki te taha Matau me te reo ki te taha MMaaui?

The two station idea is interesting in terms of some of the discussion above. Is Maori TV on the Right and Te Reo on the Left as per Zepa Theory?

Ko te reo, moo ngaa mahara teenaa, ngaa mahara o te reo me ngaa tikanga, moo te whakaora anoo o eenei. Ko te reo, he tumu, he tumu aahua, he tumu mahara hoki moo teetahi roopu nui, teetahi hapori. 
Te Reo is about memories: memories of language and culture being brought back to life and living in the now. Te Reo is a cornerstone of identies of memories, of 'our' identities. It is a statement of property owned as memory, as identity by Maori.

Kua korero a Karen Mazer mo te whakamaharatanga i a ia i rapu ai i te kapa haka me nga whakaaturanga o Mika. Ko au kai te koorero au moo mahi whakatawhito, whakatauira hoki i teenaa mea, teenaa kupu, teenaa tangata. Ko te kawa me nga mea e whai naa, ka whakauungia ki reira te hoohonu o teenaa aronga, teenaa raanei peenei.

Karen Mazer has discussed memorialisationin as consideration of Kapa Haka and the performances of Mika. I am talking about the tendency to make classic, to make Historical, if you will, this event, that word, this statement, that person. Ritual and ritual processes depend on a weighting of meaning like this.

Ko te kawa, ka whakaatu teenaa ki a koe ko wai koe anoo. Aa, kei roto i te kawa, he whakamaharatanga. Kei te kawa hoki pea ko te reo.

Ritual shows you how to remember who you are. And ritual often involves memorialisation. It also often involves a language

I eetahi waa ko te reo kawa, me kii te reo o te karakia kei teetahi aahua tawhito teenaa. Engari i te tauira Maaori he roa kee te waa o te reo ki runga marae, ki roo Haahi raanei. Engari i te tauira o te reo Maaori he uaua i eetahi waa e kite i te rerekeetanga o te reo noa ki te reo tapu. Ko nga reo taketake he reo aahua eenaa, e ai ki teenei aronga koorero, ko te reo o Ingarangi te reo whakawhitiwhiti noa. Noo te ao katoa te reo o Ingarangi. 
Sometimes the language spoken in ritual is in archaic form and this is true, say for karakia. But in the Maori case the language had been in the homes of church and marae for so long that it is difficult to disassociate ritual and regular, communicative language.

Engari ko te reo hai taaonga i raro o te Tititi o Waitangi, he mea whaia ai e Higgins me Poia me John McCaffery hoki. No wai tonu raa te reo? Naa te aha teena teenae e tono, e tapa raanei i te reo?

But Te Reo as a taonga guaranteed under Article Two of the Treaty of Waitangi has both Higgins and Poia as well as John McCaffery, as described earlier talking about te reo, the property rights thereof and the right to speak it. Who actually owns te reo Maori? Why should anyone actually own a language?

Kua wehetia ngaa teihana reo Maaori, Maaori TV me Te Reo, i runga o eenei whakaaro? Ko Te Reo kai te whai teenei i nga whakamaharatanga me nga mapihi mauria? Kai te toro atu te Pouwhakaata Maori ki ngaa whanau, te haakinakina me nga rangona kooorero o te ao. He pai rawa kia whakakootahitia eenaa teihana?

Are the two stations, Maori TV and Te Reo going in different directions in terms of cultural property and memorialisation/classicisation. For serious cultural stuff Te Reo, the station provides a language that is good for memorialisation, kapa haka, identity and the like. In terms of Te Reo Maori TV is child and family friendly, good for news and the like. Would it be better that they were integrated?

Engari raa, ko teenei rerekeehanga he whakautu ki te paatai nei? Kia whanui ai te toro o teetahi teihana, ki te iti me te rahi, maataatou, kia whakawhitihia teetahi teihana, kia niaongia me kii, he pai teenaa? 
Does this difference, this sorting out of culture and language if that is what it has been, again with the popularity of Maori Television in mind, offer a kind of solution to this? If te reo is used in common and garden ways in one zone, on one station, maa taatou, for everyone, and in a culturally defined constrained and defined way in another?

Teeraa pea, he hononga rangirua o te whakauu aahua me te ako reo. Kia mea mai teetahi he mataku ngaa maatua Paakehaa moo ngaa Koohanga Reo. Kai reira ngaa koohanga reo hei waahi ako i te reo, he waahi maa Ngai Maaori e noho pai, noho ngaawari hoki raanei? He kura aahua, he kura reo raanei?

There may be a confusion of identity affirmation and language learning. When someone says that Pakeha parents are scared of taking their children to Kohanga Reo then there are a number of questions like, are the Kohanga Reo there just for purposes of language learning or are they there as places where people can learn to be and enjoy being Maori? Are they schools of identity as well as being schools of language?

He koi kee raa te kooero mai i te hui Maangai Paaho i te timatahanga o teenei upoko.

The quote from a Mangai Paho cluster hui paper at the outset of this chapter is telling.

E tika ana maa taatou e haere ki tua o te aahua kia mau te reo i a taatou?

Do we have to talk our way past identity to retain and develop a language and keep on rigorously de-siloing things?

E koorero raanei taatou ki te aahua, ki teetahi waahi pai moo te ngaakau kia taea paingia ai te ako, te ako i te reo. Ko te aahua me toona whai, he nuka, he reanga i te arawhata raanei kia whakaarongia te whakamau i te reo me te akoako? 
Or do we talk our way into identity, into a positive emotional comfort zone in which learning, language learning in this case, can develop? Is identity and its pursuit and its politics a trap or a step on a ladder when it comes to language retention and learning?

Kei te pai haere te ako i te reo kia uaua te waa? He pai rawa teenaa ki ngaa waa ngaawari. Ko ngaa reo e ora ana he reo putea, he reo aroha raanei?

Does language learning proceed as much when the going gets tough and the tough get going, when adrenalin starts to flow as when people feel warm and relaxed and fuzzy? Are languages that survive money languages or love languages?

Ko te take e puta nei kei roo teenaa i te paatai, he lingua franca te reo he reo pure raanei? $\mathrm{E}$ taea te reo hai lingua franca i raro i te rangatiratanga reo o naaianei?

The issue of Maori as a pure language or as a lingua franca, picking up whatever is needed as and when comes to mind. Is Te Reo Maori being allowed, allowed by the language bureaucracy involved as described below, to be a lingua franca?

E ai ki te Ripoata Workman o 1998;

There is a point made in the Workman Report of 1998 that says;

to make it clearer that TMP stands primarily for the promotion of Maori language and its culture (te reo Maori me ona tikanga) as opposed to the Maori language and culture.

E tika ana kia wehikore ai te tangata e ako ana i te reo. He mea nui kia noho wehikore ai te tamaiti. 
It is appropriate that the person learning Maori be safe and of course this particularly applies to the child.

Ko te mea, he waahi pai maa te tamariki te Pouwhakaata Maori, ko teenaa teetahi mea pai moo te haere o te reo. Ko ngaa maatua, he uu kee too raatou mana, aa, ahakoa te rerekee o te reo ki a raatou kaaore teenei he mea nui moo te tukunga atu o aa raatou tamariki ki te matakitaki i ngaa pakiwaituhi me te peenei ki te Pouwhakata Maori.

The fact that Maori television is a safe place for children may have helped the development of the language. Parents feel that their authority is not threatened and the fact that the language on the station may not be their native tongue is not important when it comes to deciding to allow children to watch cartoons and the like.

He wheenaa eetahi koorero naa teenei kaituhi moo Suzie Cato (cf Cleave 1998, 2014). Kai te tuu te pouwhakaata hei matua, e ai ki ngaa Romana, in loco parentis. He hononga pea $\mathrm{i}$ koonei o te mahi matua, te aarahi a iwi me te whakatuu, pea, o teetahi iwi hou.

Similar points were made by the present author in a discussion of Suzie Cato (cf Cleave 1998, 2014) Television is in loco parentis in many respects. There is a fusion of parenting, ethnic guidance and possibly ethnic creation.

Ko teetahi waahanga o teenei, he mea taea noatia mai e te teihana moo te reo. Ko teenei he raranga o te mana matua me te wao reo.

Some of this is an unconscious process as far as the language of the station is concerned. This is a mix of parental authority and language context. 
E tika hoki ana i te waa oorite kia waanangahia teenei i te whakaaro ki runga moo te mataku o eetahi matua Paakehaa moo ngaa Koohanga Reo.

At the same time this might be considered with the point above about Pakeha parents being scared of Kohanga Reo.

He rahi kee ngaa take i koonei. Ko ngaa aahua o te tuakana me te teina i whakatakotongia naa e John McCaffery, kei te haangai pea. He whakaaro hoki i koonei moo te mea e kiia naa ko 'cultural safety'.

There are many issues involved, the tuakana- teina distinction raised by McCaffrey (Waatea April 2014) might apply here. There are also concepts of cultural safety to consider.

Ko te koorero moo ngaa silos ki runga, ka haangai hoki pea teenaa ki te take nei. He waahi wehikore ngaa silos, teenaa me oona tuu aahua me oona aawangawanga hoki moo ngaa tikanga? He waahi hoki eenaa moo te koorero o te reo. Teeraa pea ko te tino silo ko te hau kaainga me toona mahana.

The discussion of silos above might apply here as well. Are silos safety zones, each with its own statements and doubts about culture as well as being places where the language is spoken? People feel safest watching television in the warmth of their own homes in a comfort zone where they have control, the home is perhaps the ultimate silo.

E tika ana kia whakaarongia ngaa mea ki runga i roto $i$ te whakaaro, me kii, o te pai o te reo koorero. Ko te aahua o te koorero he mea ake rawa maa ngaa mea koorero $i$ te nako o te kaupapa.

The points above might be considered in terms, so to speak, of the safety of the script. How the language is spoken is not as important to some as what is said. 
Ko te whakamaharatanga, he mea nui teenaa moo nga rawa me ngaa aahua, aa, ka hangai pea nga tuhinga naa Brown (2004) me Goldsmith (2011) ki teenei.

Memorialisation is important in considerations of property and value with respect to work in Anthropology by Brown (2004) and Goldsmith (2011) on intellectual property (cf Cleave 2014).

He reo aa kawa maa taatou i te koorero mo nga mea 'on the kaupapa', 'in the frame' raanei. He tika te Mahere Zepa? E tika ana kia whaingia teetahi aahua hoou moo te reo, he aahua waatea pea? Kai te koorerongia he reo o naaianei?

Do we have a ritual script where things said are 'on the kaupapa' and 'in the frame'. Is Zepa theory correct? Is there a need for a new language, a language of the now?

He uu te hari whakaaro o te reo Maori hai Reo o te Motu?

Is the notion that Maori is a national language being taken seriously?

E ai ki te hinengaro te panui o te Pouwhahakaata Maori;

mā rātou, mā mātou, mā koutou, mā tātou

The slogan of Maori Television; mā rātou, mā mātou, mā koutou, mā tātou (for them, for us, for you, for everyone), comes to mind.

Ko taa Iritana Tawhiwhirangi, e koorero ana ia moo te kaawanatanga me te reo. Kai te maatau te kawanatanga ki te hoomai te mea i tangohia i te reo, aa, ki a ia ko te kupu tika ko 'culling'. Ka mea a Iritana moo Apirana Ngata me taana pai ki te reo Ingarangi. Kai te koorero hoki a Iritana moo teetahi haerenga, mai, i toona anoo tauira, $i$ te haerenga $i$ te Tai Rawhiti, i teetahi waahi Maori tawhiti atu ki e Kaawanatanga ki a Pooneke. E ai ki a ia, kia tonoa koe e te Kawanatanga ka taea teenaa e koe. 
Iritana Tawhiwhirangi (2014) is talking about the state and language. The state is trying to put back what it took away with regard to the reo and she uses the idea of 'culling' as with Apirana Ngata culled te reo with his emphasis on English. There is also a sense of journey to the state as in coming from the East Coast in a remote Maori speaking place to the State. There is almost a divine right attributed to the state and as she says if the government told you to do something then you did it (Tawhiwhirangi 2014: 35).

Kai te rere te whakaaro moo te reo me te kaawanatanga, te kaawanatanga me te reo $\mathrm{i}$ te nuinga o nga pukapuka peenaa $\mathrm{i}$ Te hua o te reo Maori (2014).

This attitude to the state is pervasive throughout the literature including recent work like The Value of the Maori Language (2014).

Ko teetahi tino whakaaro noo Tawhiwhirangi ko teenaa mo te 'critical mass'. Engari ko teetahi aarai nui ko te nukunuku o nga mea ki te Tahuhu o te Matauranga. Kai te haangai pea te koorero i eetahi atu waahi ki teenei tuhinga mo te rangatiratanga o te reo

Where Tawhiwhirangi is really interesting is with her idea of critical mass and this is part of her title. Having said that the difficulty in finding critical mass especially to Iritana when dealing with the Ministry of Education and its ever changing staff line-ups has been a major obstacle in her view. The discussion of language elites elsewhere in this paper may apply here.

He koorero koi taa Iritana Tawhiwhirangi mo te mea e kiia nei 'immersion', moo te ruumaki reo. Ka haangai pea te koorero moo Te Ataarangi ki taana. Ka haangai hoki te koorero moo te paanui me te tuhi me ngaa torohanga-aa-reo e kiia nei ko 'metaphors'. 
There is an interesting and important discussion of immersion throughout Tawhiwhirangi's article as opposed to other forms of education and a lot of policy hinges on this. The points made about $\mathrm{Te}$ Ataarangi above and literacy and metaphors below may also apply here.

kai te koorero a Tawhiwhirangi moo te 'silo', aa, ka hoki ia ki te whakaaro o te critical mass'.

'Government is looking for answers and we need to get their understanding of Maori aspirations. Our problem is that we are going on their (her italics)road to find solutions that should be ours but do not end up being ours.'

(2014: 47)

Tawhiwhirangi talks about a silo $(2014$ 41) and comes back to the idea of critical mass 45 2014:

'Government is looking for answers and we need to get their understanding of Maori aspirations. Our problem is that we are going on their (her italics)road to find solutions that should be ours but do not end up being ours.'

(2014: 47)

E kitea ki reira te momo nukurangi i te whakawhitiwhiyi ki waaenganui o nga roop iti me te kawanatanga.

This shows the kind of displacement that occurs when minority groups and the state interact over language.

Ka hoki a Tawhiwhirangi ki a Hoani Rangihau me te hipi preiwete me te whakaaro kino anoo mo te kawanatanga.

Tawhiwhirangi goes back to John Rangihau and bellweather sheep and the feeling/paranoia about government comes through again (2014:49).

$\mathrm{Ki}$ te rawaho e mataki noa $\mathrm{i}$ ngaa take peenaa $\mathrm{i}$ te 'immersion' me te 'bilingualism' i waenga i te Kohanga Reo me te Kawanatanga, e kore e kore he mea iti noa engari raa ko 
teena te peenaa. He kaha raa taa Tawhiwhirangi hoohaa $\mathrm{i}$ te nuku o taana tuhinga (2014:45)

To an outsider the issues with the state as with immersion and bilingualism between the Kohanga Reo and the MOE as described by Tawhiwhirangi must seem petty and as something of a distraction but that is how the situation works and Tawhiwhirangi's frustration with this position is strong throughout (2014: 45)

Kai a Mamari Stephens hoki teetahi whakaaro moo te kaawanatanag me te reo, aa, ka whai ia i ngaa mahi whakataa naa ngaa tari kawanatanga. Kia whakaarongia te reo Maori hai reo hapori ka kookiritia he whakaaro moo te teitei, te rarohenga me te pikinga o teenei. E ai ki a Parkinson (2001) ki te tau 1911 he ngoikore kee te reo hai reo hapori.

Mamari Stephens also has an idea

of state and reo and this is to do with the publication of texts by government agencies. (Stephens in Higgins et al ed 2014:68). There is a high, low and rising thesis advanced about Maori as a civic language as Parkinson (2001) suggests that at a low point around 1911 te reo Maori had become a 'largely ineffectual medium of communication' for civic purposes.

Ko te waa piki, mai i te tau, me kii 1975 , aa, mai tonu raa i te tau 1987 teenaa. He kotitihanga pea i ngaa tauira, me kii, o the whakatuu o ngaa petihana ki roo Maaori i 1968 me te tiimata anoo i 2008 engari ka whai te whakaaro nei i taa Moon (2009) me eetahi moo te Maori Rennaissance mai i te Hui Taumata o 1984.

The rising process broadly covers the period considered by Tawhiwhirangi, from around 1975 and specifically from 1987. There are variations and exceptions as with, for example, Petitions being stopped in Maori in 1968 and started again in 2008 but the general idea follows Moon (2009? tekaharoa.com) 
and others of a Maori Renaissance from, say, the Hui Taumata of 1984 .

Ko taaku tapa o 'teitei', 'rarohenga' me 'pikinga', e kitea hokitia pea teenaa i eetahi tauira. Ko taa Te Ripowai Higgins, e koorero ana ia moo te tipuranga o ngaa waananga reo i te waa 'pikinga' i aarahi mai i ngaa taangata peenaa i a Te Heikoko Mataira(ki Rawinia Higgins et al ed 2014: 269-290).

What I have called the high low and rising historical sequence above might also be seen in other historical treatments. Te Ripowai Higgins, for example, looks at the history of study groups, of wananga in the latter, 'rising' period. Her work shows the home of language development by Maori lead by such figures as Te Heikoko Mataira (in Rawinia Higgins et al ed 2014, 269-290).

Ko teetahi anoo tirohanga mai i te wa 'pikinga' ko taa McKenzie me Poia (ki Higgins et al 2014: 239-254). He hiitore pai taa raaua, aa, ka whakauu raaua $i$ ngaa rawa $o$ te kaupapa.

Another perspective in the 'rising' period since the 1970s comes from the schools in the work by McKenzie and Poia (in Higgins et al 2014:239-254). They provide an interesting history of te reo teaching and stress the positive values involved.

I teetahi anoo hiitore naa Muller me Kire (2014: 291-304) he rawe kee te koorero moo ngaa whakaaro me te mahere ako o Te Ataarangi. He koorero ki reira moo ngaa raakau hai mea tautoko ako. Ko te waiata teetahi anoo mea, aa, ka huri a Muller me Kire ki a Spolsky ki Mataira 2001: 13-05

'singing gives memorisation of text and language structure in songs'.

Kaaore Te Ataarangi e whai i te tuhi me te paanui o te reo inahoki ko te koorero te mea nui, aa, ka huri raaua ki teetahi DVD naa Hond hai mea tautoko (Hond 2002). 
In another history Muller, and Kire (2014: 291-304), in an excellent discussion of the philosophy and pedagogy of $\mathrm{Te}$ Ataarangi provide a detailed account of a learning style, This style features the use of small visual aids in the form of rakau or sticks. Singing is another feature and Muller and Kire quote Spolsky in Mataira 2001:13-05;

'singing gives memorisation of text and language structure in songs'.

Interestingly the teaching style does not emphasise literacy and Muller and Kire cite a DVD by Hond (Hond 2002) to this effect.

He aronga pai na Muller me Kire (op cit 296) ki te rongopai o te waahi ako i a raaua e huri ki ngaa take e rima o Mataira (1986). Ko eenei, he mahere pono moo te mahi pai ki te hapori. E koorero hoki ana a Muller me Kire moo te ruumaki reo Maaori (op cit. 297 cf Slaughter 1997) me ngaa kaitiaki. Hai mea whakaoti moo ngaa rawa nei he koorero pai naa raaua moo te whaamaaori o te ako naa ngaa kaumaatua. He koorero ki runga, ki raro hoki moo te Pouwhakaata Maaori hai kupenga o ngaa rawa me ngaaa rongo pai. Naa teenei te pai mai i te Hapori moo te Pouwhakaaata Maaaori, naa teenei hoki te pai o te Pouwhaata Maaori hai waahi ako i te reo.

Significantly Muller and Kire point to a sense of belonging in a safe learning environment and they refer to (op cit 296) Mataira's (1986) five points. These amount to a language learning creed that works in terms of social behaviour.

Muller and Kire also provide a good discussion of immersion (op cit. $297 \mathrm{cf}$ Slaughter 1997) and of mentors. Rounding out this mix of values there is a good discussion of normalisation involving kaumatua. It is argued above and below that this safety net or set of values to do with safety is one reason for the popularity, and hence the language learning involved of Maori Television. 
Aapiti atu i teenaa ko te mana o te reo. Ko te tauira o the Whare Paremata i te waa o Ngata, he mea uaua teenaa, aa, ka koorero a Stephens moo te waa kia kore e kooereongia te reo kia kore e noho hoki naa ki reira he kaiwhakapaneke. He mea aawangawanga teenaa moo te mana o te reo Maaori. he peeneaa teenei pea $\mathrm{i}$ te mahi o nga tuhinga ki raro, ngaa 'subtitles', in ngaa rangona koorero ki te Pouwhakaata. He mea whakapooturi pea mo te haere o te reo.

As well as safety status is important in matters of identity and property. The former situation in Parliament is curious and Stephens points to Ngata being stopped talking Maori in Parliament unless an interpreter was present. It meant that the status of Maaori was rendered precarious and at the mercy of things outside talk. The use of subtitles is similar as broadcasters will not go to air without them and they too are a constraint on talk.

Kei te ao paho te mana o te reo inahoki kia whakaarongia ngaa petihana me ngaa panekehanga o eetahi pukapuka kaawanatanga. He mea whaangai eenei ki te ao paho (cf Stephens 2014:70). Kai te whakanui ngaa kaiwhakapaho i eenei?

The media make or break the status of the language. The petitions and translations of sundry government documents mentioned by Stephens amount to a feeder to journalists (2014:70). Do they maximise the use of these?

$\mathrm{He}$ reo kawanatanga te reo Maori engari e ai ki a Stephens;'There is little guidance in the Maori Language Act or elsewhere as to what this status really means.'(2014:71). Ko ngaa waa whakamoohio, he mea whakapooturi i te reo, aa, ko te reo Ingarangi te reo e whai noa nei.

Maori is an official language but;

'There is little guidance in the Maori Language Act or elsewhere as to what this status really means.'(2014:71). There 
are notice periods required in Tribunals and the like which slow things down to the point where Maori is not used and English is the default civic language.

Ko te whakapae naa Stephens, he mea noho ki runga i te whakaaro kia mau ai te reo i te Kaawanatanga ka koorerongia whanuirawatia te reo. Wheenaa teenaa pea ki taa Tawhiwhirangi kia paingia ai teenaa e tipu ai te reo. Ko teenei he mea whakataa pea, he mea kaaore i te pai moo te reo e koorero waatea ai.

'In reality English remains the default language of the courts; even in the Maori Land Court, the right to use the Maori language is more theoretical than real.'

(2014:76).

The argument put forward by Stephens assumes that the adoption of Maori as a civic language would make Maori more widely spoken and understood. There is also as with Tawhiwhirangi the feeling that if it is allowed the Maori language will flourish. This amounts to a conditionality, a hesitation one which possibly cannot be afforded for the language to be spoken in a free and uninhibited fashion;

'In reality English remains the default language of the courts; even in the Maori Land Court, the right to use the Maori language is more theoretical than real.'

(2014:76).

Ki teenei tauira ko te mana whakataarewa, he mea whakapooturi i ngaa aahua ngaakau, hinengaro hoki moo te koorero i te reo.

In this way the conditional status of Te Reo Maori is an inhibitor in emotional and philosophical ways as well as being a brake on actually speaking the language.

E whakahokia ana te reo ki te iwi ki te whenua raanei?

Is Te Reo being returned to the land or to the people? 
kia huri ai taatou ki te paatai mo te iwi me te reo, e tika ana kia whakaarongia taa Veroniva Tawhai moo ngaa tangata whenua me ngaa rawaho (Tawhai in Selby et al ed 2010). Ko te pai o taa Tawhai, ka taea te whakaaro moo ngaa taangata whenua me te whakaaro moo ngaa rawaho $i$ te waa oorite. $E$ tika ana kia rarangihia te mana whenua i te mea tuatahi engari e tika hoki ana kia whakaaarongia ngaa aahuaranga o ngaa raawaho. He peenaa pea te huarahi tika moo te reo, kia rua ai nga whakaaro moo eetahi kupu, rarangi kupu, kiiwaha, whakataukii me te peenaa engari kia whaingia he aronga pai moo te huarahi koorero.

This might be considered in various ways, locally to Veronica Tawhai's work on tangata whenua and Zawahiri (Tawhai in Selby et al ed 2010). A great value in Veronica Tawhai's work on attitudes and responsibilities to the Environment is that it shows a two model approach where people consider the rights and circumstances of locals, tangata whenua, as they also consider the rights and circumstances of people from outside of the tribal area, rawaho. The circumstances of locals and their traditional reo, their iwi reo, reo aa iwi, are to be respected and take precedence. At the same time there are newcomers to be heard in the locale...

Kia whaingia, kia whakahoungia hokitia te reo taketake o te rohe e tika ana hoki kia kitea, kia whakahaapaitia hokitita pea te reo e aata koorerohia nei ki te rohe. Hai tauira i tooku rohe e tika ana kia aata whakaarongia te reo tuuturu o Rangitaane, aa, kia whakaarongia hokitia te reo koorero ki runga reo irirangi, ki roo kura ki hea raanei e nga raawaho me nga tangata whenua hoki.

Just as the reo of tangata whenua needs to be preserved, retrieved and revived so there is a need to look at and encourage the reo that is actually spoken in the area. For example in the Rangitaane area there is a need to preserve, 
retrieve and revitalise the Rangitaane dialect but there is also a need to look at the language actually spoken on the radio, in hui and in the schools in the Manawatu by outsiders as well as locals.

Teeraa pea, he paatai whaanui rawa ki koonei. Ka korero a Foucault moo te putahanga mai o te tangata $i$ te hinengaro o Uropi. ki te rau tau tekau maa iwa. I mua o teenaa ko te Atua me te Haahi ngaa mea nui. Ki koonei e tika ana pea kia whakaarongia eetahi atu mea $\mathrm{i}$ te tangata me te iwi kia whaingia ai te huarahi koorero pai moo te reo.

There might be wider questions here. Just as Foucault argued that there was an 'emergence of man' in the nineteenth century and people began to think of individual and group control of things rather than a preordained order, here it may be important to think about an order of things that goes beyond iwi and individual as far as te reo and, possibly, other things outside the scope of this paper, are concerned.. This applies to ownership and identity. internationally to Foucault and his 'emergence of Man' thesis.

Teeraa pea e haangai ana taa Foucault ki a Mahere Zepa inahoki kai te whai te Mahere Zepa ki te ao o te tangata tonu i toona anoo waa, waahi hoki kaaore e whaia nei te ao o neheraa. E koorerongia pea he nukuranga peenaa $i$ teenaa $i$ meatia ai e Foucault.

Foucault is talking about the development of consciousness about man and the human condition as distinct from things being God-given. This is the much noted 'break in the table'. It might relate to Zepa theory in that the latter calls or seems to call for a consciousness of where the person is at rather than where the tribe and the ancestors are or where they have been; the language carries the past as a matter of custom and this is queried. Zepa theory is not- or at least not necessarily- a call for the Person to come out as 
much as a call to attend to the immediate environment, the context of the now.

Ka haangai, hookai raanei pea taa Fukuyama ki taa Foucault me taa Foote, taa Kawharu hoki. kua koorero a Foucault moo te wao o te tangata ki roto o toona anoo waa, aa, kua koorero a Fukuyama moo te nunumi o teenaa. Teeraa pea ko nga whakamaharatanga e koorerongia naa e Foote me te whakaaro o te waahi e meatia naa e Kawharu, he mea whakanui aronga moo te tangata. He aawangawanga naa eetahi moo teenei. E ai ki a Schama ka waihongia ngaa mea 'paapaku' wheenaa i te ahua whakapono, aahua iwi raanei Teeraa pea ko te reo te mea waiho noa atu hai mea timata hai mea whakoti raanei..

Fukuyama's 'end of History' thesis can be related to Foucoult's ideas as, I think, can Kenneth Foote's. Foucault's emergence of Man is about the consciousness that Man can create a Destiny, a History. Fukuyama suggests that is all over. The way people attach to memorialisations of events as described by Foote or the way people attach to the locale as suggested by Kawharu gives meaning to their lives in this context. There is doubt about all this. Schama in a recent BBC interview with Fukuyama seems to suggest that we are left with the emptiness and shallowness of ethnicity and religious difference (BBC June 2014). In such a context language offers a way of attachment, a way to identify. After History, after Memory, after Place, after Ethnie there might still be language. At a point where identity begins and ends.

Ko nga whakaaro peenei, kai te haangai eenei ki te tohe ki waenganui i a Levi Strauss me Sartre, nga hapori makariri e noho naa i te wao pakitara, te wao whakamaharatanga me nga hapori wera $\mathrm{e}$ aro naa $\mathrm{ki}$ te hiitore, ki te waa o naiatonurawaatunei. I te Mahere Zepa ko te wawata kia nuku ai i te ao koohatu ki te ao hurihuri, i te ao makariri, ki te ao wera. 
This kind of thinking might relate also to Levi Strauss $\mathrm{v}$ Sartre, cool myth based societies with their memorialisations and hot, present based societies that have, after Zepa, Right Shifted into a focus of the present and historical rather than mythical explanation.

He moemoea ki te whenua mo te reo, he peenei te haere; Kai te tuu mai te Tiriti o Waitangi hei maru kaawana, kaawanatanga mo te motu me kii. Kua tahae te reo $\mathrm{i}$ te kaawanatanga, aa, maa te kaawanatanga te whakahokinga. Kia taea ai teenei he nama ki te kaawanatanga moo te reo. Kia paanuitia te Rautaki Reo Maaori e kitea whaanuitia ai te whakaaro moo te hononga $i$ waaenganui i te karauna me ngaa iwi moo te reo. Kai te whai teenei i te hiitori o te motu engari e tika ana pea kia whakatakotongia te paatai, he huarahi pai teenei kia whakahoungia ai te reo?

There is a dream about Te Reo extant in the land and it goes something like this; there is a Treaty, The Treaty of Waitangi, and this stands for a state, as in the expression, 'nation state'. The trappings of the Nation State involve the theft of Te Reo and then its return. There is a language debt owed by the state until such redress occurs. Reading Te Rautaki Reo Maori of 2014 the idea that a language will develop in a partnership between the state and an ethnic group, the New Zealand government and Maori is pervasive. And so, given the history of the country, things should be. But is such an attitude a way to ensure language survival?

He rore, he cul de sac raanei, teenei?

Or is this a trap, a cul de sac?

He huarahi anoo ki mua?

Are there other ways forward?

Teeraa pea e nukunuku kee raa te reo i eenaa mea, teeraa pea he reo e tuu i te ipurangi, i te pouwhakaata, teetahi wahi atu $\mathrm{i}$ te kaawanatanga. He raahi kee nga 'kaainga', ngaa 
nohoanga me kii moo te reo mai raano. E tika ana kia aata rangahaungia teenei inahoki $\mathrm{i}$ teenaa nohohanga teenaa raanei e kitea teetahi reo pai, teetahi ahua hoki moo teenaa nohoanga.

Perhaps the language is moving away from these traditional speaking and listening places, perhaps it will increasingly be a language of the net and the television, away from the marae, the home and the state, in an ether world with its own identity. There have been many homes for te reo over a long period. These are worth researching as each home has had its own language form and its own identity as well as being owned in a specific way. 


\section{Literacy}

E ai ki a Stephens (op cit 2014) kaaore te ao paho e whai ana i ngaa whakataa ki roo reo. Ko te puutake o teenei kaaore ngaa taangata- kaiwhakapaaho, te hapori whaanui raanei- $\mathrm{e}$ akona ana ki te paanui ki roo reo. Ko te reo Maaori, e ai ki teenei tirohanga (cf taa Hond 2002), ki te Koohanga, Te Kura Kaupapa me ngaa Waananga, he reo koorero, kaaore he reo tuhi, he reo tuku iho kia koorerongia ki waaenga taangata.

Stephens (op cit 2014) suggests the media do not pick up on publications in Maori. Is this because people- audience and journalists alike- are not taught to read in Maori? Maori, so this argument goes (cf the reference to Hond 2002 in the discussion of Te Ataarangi above), in the Kohanga, Kura Kaupapa and Wananga is a spoken language, part of an oral tradition and so it should be shared and spoken as such.

Kai te haangai te kapa haka me te Pouwhakaaata Maori me te reo irirangi hoki ki teenei. Ko te hono i te hiitore o te Pouwhakaaata Maori me te reo koorero ki roo paremata he mea haangai hoki; he taapere aa reo koorero teenei.

Kapa Haka as an activity fits this description as does Maori Television and radio. The convergence mentioned several times here between the advent if Maori Television and the speaking of Maori in and around Parliament fits here as well; this is primarily oral drama.

Engari he mea uu rawa te paanui me te tuhi i te reo. Itiiti ngaa haangai, hookai raanei ki te take paanui, tuhi raanei o te reo i te pukapuka, Te Hua o te reo Maori (2014), haunga anoo i taa Ngapo ki a Baker me Jones, aa, he tohu teenaa pea ki te rangahau i te reo me toona whakaora anoo. I eetahi waa e kitea ana he whakaaro noa moo teenei i te tauira, me kii o Instant Maori inahoki ko teenei teetahi o ngaa pukapuka paanui whanuitia $i$ te tekau tau kua mahue engari atu o teenaa he marino kee teenei wahanga o te rohe reo. I eetahi 
waa e kitea ana teetahi whakararohanga o te mahi paanui peenaa i teenaa ki te Ataarangi (cf Muller me Kire moo Hond 2014)

But there really is no way around literacy. A citation of Baker and Jones in Ngapo's essay in Higgins et alia, The Value of the Maori Language (2014) is one of the few references in that book to literacy and that seems indicative of research into te reo and its revitalisation. Sometimes there is a hint of an 'arc', of a feeder situation as with Instant Maori, one of New Zealand's biggest selling books over a decade or more but otherwise this part of the language field seems quiet. In fact there is almost an anti-literacy approach in some areas such as Te Ataarangi (cf Muller and Kire's reference to Hond 2014).

E tika ana pea kia whakaarongia te paanui me te tuhi ki te reo maa runga $i$ te ipurangi. Ka koorero a Keegan raaua ko Cunliffe (2014:64) mo eWananga me eetahi mea. E ai ki a raaua he puu kee raa ki te ipurangi o ngaa mea Maaori (op cit :390). E tika ana pea kia pataingia e hia ngaa taangata e paanui ana i eenei mea? Ko te whakautu ki teenaa paatai, he peenaa pea ki taa Stephens moo te whakanuihanga o ngaa tuhinga ki roo reo mai i te kaawanatanga, he mea kohi puehu kee raa eenaa.

There may also be a need for literacy on the net at least as far as writing comments in Maori is concerned. Keegan and Cunliffe (2014:64) discuss eWananga (2014:389) and other developments. They talk about an explosion of content in te reo on the web (op cit:390). It might be asked how many people are actually reading this content? Is it, to follow up on the point made earlier by Stephens about a similar period, like the increasing amount of government papers in Maori that are unread or not commented upon?

Kai te koorero a Keeegan raaua ko Cunliffe moo ngaa raarangi e rua o ngaa tuhinga ki roo Maori, reo Paakehaa hoki. E ai ki a raaua he aukati teenei. Kai te koorero hoki 
raaua moo te iti o nga rohe moo Maaori ki te ipurangi (op cit :394). He aahua aawangawanga a Keegan raaua ko Cunliffe moo te toro (op cit :396) me eetahi mea wheenaa i te utu (op cit: 394).

Keegan and Cunliffe talk about the situation of parallel texts in English and Maori on the net and consider this a barrier and they also talk about the restricted number of domains for Maori on the net (op cit 394). There would seem to be a need for research on the usage of such domains as are used and Keegan and Cunliffe raise a concern about the range involved (op cit: 396 ) as well as talking about cost (op cit 394)

Ko te whakapae ki koonei pea ko te whai i ngaa koohua, ngaa waro me ngaa kuuaha i waenganui i eenei waahi reo e rua. He aahua oorite pea ngaa reo o Ngaa Paaniora me te reo Ingarangi ki Amerika, aa, he take rangahau ki koonei pea. Kia waanangahia te take nei ki waenga o ngaa mako e rua he ngaawari atu te kitenga o te take $i$ waenga $i$ te kahawai me te mako (cf Kelly 2014).

The challenge might be to find links, holes, passageways, tunnels between parallel domains. Similar things happen with Spanish and English in the USA and there might be a case for research in this area. If we could deal with the SpanishEnglish default situation between two so called 'predator' languages (Kelly 2014) then we might better see how to deal with the Maori-English default situation between a predator and a minnow.

Teeraa pea e hono ana te paatai o ngaa mahi tuhi, paanui hoki ki eenei raarangi e rua ki te akoako ki te teitei o ngaa kura tuarua moo te mahi toi reo. E whakaaro anootia aa Karetu mo teenei (2014)

It may be that literacies in parallel or adjacent domains relate to education in the upper secondary school with literacy 
and metaphor generally and one thinks of Karetu's concerns in this area (2014).

Kia whakaarongia taa Te Ataarangi moo te paanui me te tuhi e koorerongia ki runga (cf Hond 2002) teeraa pea e tika ana kia meatia he kauwhata kore rongo moo te tuhi me te paanui. Ki Te Ataarangi kaaore kau he reo Paakehaa he waahi ki tua o te reo Maaori inahoki kaaore e paingia ana te koorero Paakehaa noo reira e kore e taea te koorero moo ngaa raarangi e rua moo te aha raanei tae hoki raa ki te tuhi me te paanui. Ko te raru pea he rahi ngaa tuhinga inaaianei ki te ipurangi, aa, e tika ana kia mohio ai te tangata ki te paanui, tuhi hoki moo teenaa (Taylor me Ward 1998)

Given the attitude of Te Ataarangi to literacy as described above (cf Hond) and the general silence elsewhere we might talk about a structure of a silence around literacy (cf Coulon 1978). In Te Ataarangi English is definitely not a default language in the first place as people are not allowed to converse in English so to talk about a default literacy between say, two parallel language discourses on the internet is to be in a very different place. The difficulty these days is that more people are using the internet more and a lot of material on the net is in text and requires literacy skills (Taylor and Ward 1998).

E tika ana pea kia hoki ai taatou ki te whakaaro moo te rangahau i taea ai e Paora Moon (2000), e Mihaere Jackson (1967) hoki pea moo te tuhi me te paanui. E ai ki eetahi he pai kee te tuhi me te paanui i ngaa tau moata o te hono o Ngai Paakehaa me Ngai Maaori e tika ana pea kia rangahaungia ai teenei i teenei rautau. Ka whai teenei kaituhi i te kaupapa nei i teetahi tuhinga e kiia nei Seen heard, written read ki tekaharoa.com (Cleave 2010). E tika ana inaaianei pea kia aata arotakengia te tuhi me te paanui ki te reo Maori, aa, kia arotake hokitia ngaa mahi e haangai nei ki te whakahouhou i te reo. Anoo, ko te reanga teitei o te kura tuarua he tino waahi moo te rangahau peenei. 
There may well be a case for research building on Moon (2000) and going back to Jackson (1967) Where there seems to have been initial success in Maori literacy in English in the nineteenth century, Maori literacy in Maori in the twenty first century might be worth exploring. An essay by the present author entitled Seen, heard, written, read in tekaharoa.com (Cleave 2010) goes over some of the background. There may now be a need to look carefully at literacy in te reo Maori and to evaluate the uses of literacy in language revitalisation. Again, also to carefully look at literacy in the upper secondary school.

Ko teetahi mea ki koonei ko te rangahau moo te tuhi me te paanui me nga aronga nuku, me te haangai tonu raa. Ko Resnick me Resnick (1977), e ai ki a raaua ka rerekee haere te aronga o te tuhi me te paanui ki muri o te pakanga tuatahi i te piirangi moo teetahi moohio teitei. He peenaa teenaa $i$ te putahanga o ngaa mihini whakaaro me ngaa mahere puunaha hou tae hoki ra ki te rorohiko me, a muri, te ipurangi. Ko te whakaaro matua i koonei he whaanui rawa te tirohanga me te papa aronga i teenei mahi teitei.

Part of this to do with defining literacy and its changing meanings and relevance. Resnick and Resnick (1977) suggest that the demand for a sophisticated, 'higher', literacy is post World War I. This would coincide with several developments including thinking machines and systems theory (artificial intelligence and the rise of the computer) and, later, the internet. The general idea is that there is a wider scope and a greater metaphorical field involved in 'higher literacy'.

Kai te piirangi taatou kia whakaterengia, whakapaingia hokitia te waa ako moo ngaa mea rahi rawa i te waa oorite. Ko te raru i koonei ko ngaa raarangi tuhi reo e rua ki te ipurangiIngarangi me Paniora, Maaori me Ingarangi, ko te reo Ingarangi te mea tuarua $\mathrm{i}$ te nuinga o te waa, ka rongo anootia ki koonei; e rua ngaa reo moo teenaa teenaa e whai i te tuhi, te 
koorero me te paanui. He pai kee eetahi o ngaa rangahau moo teenei

(Acosta 2009 cf Beykont 1994, Collier 1987, Cummins 2000, and Strong and Prinz 2000) .

We want to learn better and faster about more things at the same time. The idea of parallel domains or parallel literacies between Spanish and English or Maori and English, English always being the default language, echoes here; participants need to be doubly literate in spheres of literacy that involve complex readings, speakings and writings. There is some very sound research on Language Minorities Developing Multiple Literacies (Acosta 2009 cf Beykont 1994, Collier 1987, Cummins 2000, and Strong and Prinz 2000).

Kei te koorero a Bereiter me Scardamalia (1987a) moo ngaa kaiako $\mathrm{A}, \mathrm{B}$ me $\mathrm{C}$ hoki. Kia uru te akonga ki te reanga teitei o Bereiter me Scardamalia e tika ana kia waihongia te ao i mua tonu i a ia kia waatea ai te akonga ki te whakaaro moo eetahi wao.

Bereiter and Scardamalia (1987a) talk about Teachers A, B and C. In order, to enter a fully operative 'Higher Literacy' context Bereiter and Scardamalia's Teacher $\mathrm{C}$ must have students who are 'disembedded'. This term is used to describe a situation where apparently the student is not fettered by too literal a form of literacy, in other words by the constraints of local understandings.

Kia whaia ai tenei e te kaiako he whakapae tonu i mua ia ia. Kia pekepeke atu ra te akonga i teenaa rohe tikanga, rohe aronga, rohe reo raanei, ki teenaa, teenaa, ka waihongia te hau kaainga.

So if literacy is defined in this way there are obviously challenges for the teacher. If the student is skipping across 
metaphorical fields and in the case of bilingualism across languages and the metaphorical discourses attendant upon those languages then, rather obviously the local context is being left behind or at least put into comparative context.

Ko ngaa kaiako naa Bereiter me Scardamalia A,B me C, he peeraa eeraa i ngaa wao. Ko te paatai, he aha te peehea o te nuku ki te wao tuatoru?

Bereiter and Scardamalia's Teachers A, B, and C are like three dimensions. The question is how do you get into the third dimension?

E tika ana moo te akonga e pai ki ngaa kupu me ngaa torohanga o ngaa kupu me te taperepere i eenei hai mea tuatahi kia taea ai te wawata o Bereiter me Scardamalia. Meenaa he wao peenei i teenei nei ki Aotearoa, he wao kei roto naa a NZQA me ngaa whakararohanga o te mahi ako me te wareware o te hohonu me te toro o teenaa kupu, teenaa raanei e kore e kore he raru teenei atu i te ao reo Maaori.

The learner has to like metaphor and metaphorical play to begin with for anything like what Bereiter and Scardamalia are suggesting to occur. If there is a situation where the local educational context as characterised, say, by NZQA is literalistic rather than metaphorical, where things are concrete if not to say 'dumbed down' then there may be local difficulties beyond the Maori language and people interested in it.

Mai $\mathrm{i}$ te waa o ngaa tuhinga naa Bereiter raaua ko Scardamalia (1987a) kua tae mai te ipurangi me ngaa mea e kiia nei ko 'links', hononga. Kia aata waanangahia eenei hononga e tika ana kia whakatakotongia te paatai; e aha te reo Maori ki tenei wao hononga? Kai te titiro taatou i eetahi whakapae hou $\mathrm{i}$ te tuhi me te moohio (cf Bereiter me Scardamalia 1987b) e haangai, hookai raanei ana ki te reo taketake o Maaori? 
Since Bereiter and Scardamalia's work referred to above (1987a) there has been the advent of the internet and concepts and practices like links. Is a link like an analogy or like a metaphor or is a link a part of a web of likenesses such as found in the computer languages of, say, Erlang and seen, say on Facebook. Are we looking here at another set of challenges in language likeness, in writing and comprehension (cf Bereiter and Scardamalia 1987b) that applies to the indigenous language such as Maori in a variety of ways?

Ko te pikitia whaanui o eenei moumou mea kei roto o teena ko taa $\mathrm{x}$ mo Homo Ludens me taa Best moo the Whare Taapere pea.

Kia whakawhanuihia te tirohanga e tika ana pea kia whakaaaro anoongia taa Huizinga (1970) mo homo ludens, taa Peehi mo Te Whare Tapere raanei.

To take a broader view of this the work of Huizinga (1970) on homo ludens or Best on Te Whare Tapere might need to be reconsidered.

Ko teetahi raru moo te whakaaro aa iwi atu i te pikitia whaanui ko te kaupapa e whaia e te iwi kai te rohe tonu o te iwi teenaa. He rahi nga tuhinga moo te piri o te reo o iwi ki ngaa tikanga me ngaa reo o te ao hai reo whakawhiti koorero. $\mathrm{E}$ tika ana kia whakaarongia te toro o eenei moumou reo. $\mathrm{E}$ tika ana hoki kia whakaarongia nga pukapuka e tapangia peenaa i teenei; Jihad vs McWorld (Barber 1995).

One difficulty with the tribal as opposed to the general approach to education is that the former usually stays grounded in the local. As well as the literature talking about the minority language as the language of custom and identity the majority language being to do with communication and the use of metaphor in each of these spheres there is the literature by, say, Barber (1995) and others with titles like Jihad vs McWorld that must surely give pause for thought here. 
Ko teetahi o ngaa pito tipu, ko ngaa kaikoorero reo rua, e tipu pea $\mathrm{i}$ te paanui me te tuhi $\mathrm{i}$ te reo. Ko teetahi rohe nukunuku ko nga waahi tuhi ki te ipurangi i nga whaarangi peenaa i Facebook inahoki e tika ana maa te tangata e tuhi e paanui hoki. Ko eetahi o eenei kaikoorero reo rua, he mea matatau ki te paanui me te tuhi.

One of the key potential points of development set out here, that of second language learners, might well develop through literacy and given an arc or feeder situation such as we have with comments sections on Facebook where writing is required and which might be used by second language learners used to writing as a matter of course, this space could be worth watching.

Teeraa pea e koorero ana taatou moo eetahi kaikoorero anoo me teetahi reo anoo. Kaaore eenei taangata e whai ana $i$ te mita o teenaa iwi teenaa. Teeraa pea e whakarongo ana raatou ki te reo $\mathrm{i}$ te reo irirangi, e maatakitaki raanei, whakarongo hoki ki ngaa mea koorero ki te pouwhakaata Maaori engari kaaore taatou anoo e koorero ana. Ahakoa teenaa he mea whai reo Maaori kee eenei taangata, aa, e tika ana kia maatakingia teenei waahi.

We may be talking about a new language as well as a new set of speakers as these speakers may not be following the meter and idiom of any iwi. They may be listening to Maori on the radio and watching people speak Maori on television, reading Maori and watching and listening on the internet to speakers but not speaking it themselves. They may be living in a different language world with another form of language again but it is a real dimension, something to work with, a point of development. 


\section{Language leaps He peke reo}

He tika taa Stephens moo Koro Wetere inahoki ko teenaa teetahi o ngaa taangata $i$ whakatuu ai i ngaa tikanga o te whare paremata kia koorerongia te reo moo teenaa take teenaa raanei ki reira i raro i te Ture Tuu 104,

Koro Wetere as Stephens points out was instrumental in creating standing orders whereby Maori could be used in parliament this is important as an unqualified right to address any issue in Maori under Standing Order 104.

Anoo, ko taaku moo te 'huarahi whaangai', te 'whitinga' raanei, e haangai ana teenaa ki koonei. Kai te koorero a Stephens moo te huinga o te ao paaho Maaori me ngaa mema paremata (Stephens 2014:77).

Again, what I have called a 'feeder situation' or an 'arc' is important here and Stephens talks about the intersection of Maori media and the MPs (2014:77).

I ngaa tauira peenei e kitea ngaa hononga pai. Ka whakawaatea te paremata i te reo i teetahi Ture rerekee, aa, ka taea teenaa i te waa oorite o te whakatipuranga o te reo irirangi Maaori me te Pouwhakaata Maori e whai reo ana. I teenei tauira e kitea te hua me te tuari, te mihini me te taraiwa, aa, Kia whai anootia ai a Ruchstuhl, he puu tino pai.

In examples like this there are a set of happy coincidences where the Parliament frees up the use of the use of the reo through an obscure ruling. This coincides with developments in Maori media such as Maori radio and then Maori television both of which need feed, need talent, need forms of Te Reo, the vocabulary and the constructions. So there is product and distribution, machine and drivers, there is an optimal, to use Ruckstuhl's terms, source situation. 
Ko enei huarahi whaangai, waa whangai raanei he mea tino nui ki a a au. ka honoa, teenaa toopito me teenaa i te reo, aa, ka puuawai teetahi rohe reo hou. Ko te Pouwhakaata Maaori teetahi anoo tauira inahoki kua honoa te whanau ki te reo ki reira inahjoki he waahi pai moo te ora hinengaro, ngaakau hoki te Pouwhakaata naa, aa, he waahi ngaawari moo te whakatipu reo.

These 'feeder situations' are extremely important in my view. The language arcs between points like a spark between conductors, it connects where formerly it did not and as this happens new markets, new locales are found and created. It has been suggested that Maori Television has created a language situation where a new language locale has developed. This is a safe viewing situation and a family learning situation and, as these operate, an optimal language source.

Ko eetahi nukuhanga, kaaore he peke, he ngoi raanei. E ai kii a Stephens, ahakoa kua whakataa ngaa pukapuka kaawanatanga $\mathrm{i}$ roto $\mathrm{i}$ te reo, he itiiti rawa te whakamau o eenaa $\mathrm{i}$ te ao paho. He mahi urikore teenei ki a Stephens (2014:81). He tuari engari kaaore he piirangi.

Some movements that look like leaps turn out to be quite small. Against the positives of Maori in parliament Stephens offers the thought that while government documents are published in Maori they are not taken up by media in the way that they were in earlier times and now the effect is 'passive and sterile' (2014: 81). There is the supply but not, apparently, the demand.

He mea poouri rawa pea ki a Stephens ko te nako o eenei tuhinga kaawanatanga, kai roto i te reo Paakehaa eenaa tae hoki raa ki te Kooti Whenua Maaori me ngaa mea mai i te Taraipunara o Waitangi (2014:81).

Even more depressing is the point that the substance of documents- Stephens puts the word substance in italics- is in 
English even in Maori Land Court and Treaty of Waitangi documents (2014:81).

I te nuinga o ngaa waa ki a Stephens, he pooturi rawa teenei, aa, e koorero ana ia moo te tipu, te hinga me te 'partial renewal' o Maaori hai reo o te hapori kaawanatanga (2014:82).

Generally Stephens sees recent progress as slow and limited and speaks of the 'rise, fall and partial renewal' of Maori as a civic language' (2014: 82).

E ai ki a Stephens ko te reo Maaori ki te Paremata, he reo Maaori anoo. Engari he poouri kee ia moo te Ture Reo Maori;

Rather than facilitate te reo Maori in the courts and in official life the Maori Language Act by way of its limited statutory entitlements and subsequent clumsy notice provisions imposed in the courts frustrates use of te reo.

(2014:82)

Stephens suggests that in Parliament Maori has become an 'ordinary language'. One disappointment for Stephens is the Maori language Act;

Rather than facilitate te reo Maori in the courts and in official life the Maori Language Act by way of its limited statutory entitlements and subsequent clumsy notice provisions imposed in the courts frustrates use of te reo.

(2014:82)

Kai te koorero a Stephens moo te Kaawanatanga hai tangata, te reo hai whare;

Indeed the Crown itself will need to reside in the language house that was envisaged by the writers of the Te Reo Mauriora report; at least within the rooms set aside for civic purposes. (2014: 83)

The Crown is imagined as a person as Stephens finishes by saying; 
Indeed the Crown itself will need to reside in the language house that was envisaged by the writers of the Te Reo Mauriora report; at least within the rooms set aside for civic purposes. (2014: 83).

Ko te tuhinga naa Stephens, peenaa i teenaa naa Tawhiwhirangi (2014), Karetu (2014) hoki ka noho teenaa ki runga o te kaawanatanga, a, ko te wawata kia taea te nuku, te peke reo i runga anoo i ngaa ture me ngaa mahi naa te kaawanatanga.

The essay by Stephens shows a dependence on and a location in the state as do other essays in Te hua o te reo Maori (cf Tawhwihirangi, Karetu 2014). The disappointment that such writers have in the Act might be because a language leap was expected.

Kai te tika taa Stephens i taana aro ki te reo-a-hapori, aa, ko taana wehenga e toru he tika hoki teenaa. He poouri kee te whakaaro he ngaawari maa te kaawanatanga e wete $\mathrm{i}$ te reo. He hononga noa eetahi peke reo peenaa i te tauira moo Koro Wetere $\mathrm{i}$ te whare paremata, kaaore he mea maheretia katoatia e te kaawanatanga.

Stephens is correct to point to a civic language, and her division of three historical periods seems accurate. That in itself is quite sobering. The language tap can be turned off and on by government in an apparently whimsical kind of way; a bright spot can become dark very quickly as the state proceeds. The use of the reo in parliament since Koro Wetere used, wittingly or unwittingly a standing order to allow the language to flow shows something of a happy historical accident and certainly not a matter of conscious state planning.

Ko te whakaaro o ngaa pito maarama, he whakaaro pai pea teenaa, aa, i te whakateperanga e whai nei ka hiikoi anootia teenaa huarahi koorero. 
The idea of 'bright spots' or what I have called 'arcs' or 'feeder situations' or 'language leaps' is really important though and the identification of such is important. In the conclusion a set of such growth opportunities are envisaged. 


\section{Conclusion}

He rahi ngaa whakaaro kia whaia ai pea ki koonei. Ko te reo tonu me ngaa kaainga, ngaa wahi hoki o te reo eetahi. Kua taea hokitia te koorero moo ngaa reanga teitei o te mahi whakahaere o te reo, o ngaa tari reo me te rangatiratanga o te reo. Aapiti ati i eenaa mea ko te peka me te peke atu o te reo peenaa i taa Koro Wetere ki te whare paremata, te pai o te Pouwhakaata Maori hai waahi whanau, hai waahi pai moo te hapori kia pai ai te ako me te koorero i te reo, ngaa hononga peenei e toro na ki eetahi anoo pekanga, tipuranga hoki.

There are a fairly large number of points that could be considered. There is the language itself and a consideration of language 'homes' and situations as locales. There has been the consideration of elites, of language bureaucracy and control. Also there has been the suggestion of the arc, the breakout possibility, the feeder situation; Koro Wetere and the change in house rules to allow more Maori and then more broadcasting in te reo as that was required by Maori Television and Te Karere, the Maori Radio Stations and National Radio. Maori Television as a family friendly, safe zone that allows the family to learn by listening and being entertained, things that inadvertently, almost by accident converge with other things to allow advances.

Teeraa pea he whaaiti rawa ngaa whakaaro moo te reo $\mathrm{i}$ ngaa waa o mua. Kia whaaiti rawa te tirohanga he aahua oorite kee pea ngaa mahere e puta ake. Kia iti rawa atu te hoopua whakaaro teeraa pea ka pau haere ngaa huarahi tuuwhera moo te whakahaapai i te reo.

It may be that in the case of Aotearoa and language the theoretical field has been too restricted for too long. In a narrow theoretical range the literature cited gets to have a sameness as do the strategies generated. With the idea of a restricted pool we come back, perhaps, to ecological theory and the thought that this theoretical niche may be exhausted. 
E iwa ngaa waahi moo te reo e koorerohia nei; te kaainga, te kura, te kaawanatanga, te ao paaho, te kapa haka, ngaa kaumatua, te mahi tuhi me ngaa kaikoorero reo tuarua.

I have referred to nine locales for the reo; te kainga, the home, te kura, the school, te kawanatanga, the state, te ao paho, broadcasting, kapa haka me te ao tapere, dance and theatre, kaumatua the elders, mahi tuhi, literacy and kaikoorero tuarua, second language learners.

Ko te nuinga o eenei he mea whaia i mua. Engari ra kua koorerongia eetahi mea wheenaa i te tuhi me te panui kaore e aata whaingia ana i ngaa tuhinga moo te reo Maori i teenei whenua.

Most of these are the 'usual suspects'. Having said that there has been an emphasis on such things as literacy that are not emphasised in the literature on the Maori language in this country.

E tika ana hoki kia tirohia ngaa huarahi kaaoere i hikoi ai, ngaa kuaha kaaore i tuwhera ai. Ko te panui me te tuhi i te reo teetahi tauira. He hapa anoo teenei.

It is also important to look at areas not used, at chances or options NOT taken. For example the use, or rather the non use of literacy and the lack of attention to literacy as a key language tool may be, as suggested above, a mistake.

E tika ana hoki kia aata moohio ai he aha te aha i ngaa mea kaaore e puea ana wheenaa raa i te Punga Net me te reo irirangi Maori. He nui te putea moo teenaa, aa, kia kore e whakahaapaitia ana te reo e tika ana kia rapua ai ngaa puutake.

And there is a need for realisation as when, with considerable expense, something like the Punga Net with the 
iwi stations is established. If it is not acting as a language multiplier then the analysis needs to be done as to why not just as it needs to be sorted out where exactly it is working well.

He mea nui hoki kia moohiotia ai te kaha moo te reo me ngaa mea e whai naa. Hai tauira kia whakaurungia eetahi kupu hou moo ngaa raa o te wiki me ngaa maarama o te tau, aa, ka taea te whakatinanatanga o te mahere ki eetahi whakaaturanga rangona koorero ki te Pouwhakaata me eetahi atu waahi engari kaaore e taea teenaa i te nuku o te whenua kia moohiotia teenaa. Kia hoki ai taatou moo taa Karetu moo te gobbledegook he pai kia mataungia eetahi mea hou, hai tauira eetahi kupu mai i a neheraa, eetahi mea hou rawa raanei. Ka tuutaki pai pea teenaa hononga i te whakaaro ki te kupu. Kia kore e tuutakihia teenaa e tika ana hoki kia moohiotia ai teenaa.

And it is important to recognise power and its consequences over language as when one body decides that the days of the week and months of the year should be renamed and so this happens across a few television news services and in schools but not uniformly on marae and elsewhere. To come back to Karetu's discussion of gobbledegook; anything goes in what works. There may be a resurrection of old terms, there may be a use for completely new words...whatever it takes. The important thing is to keep trying with combinations, links, synergies, magical and other arrangements. Sometimes these attempts at new combinations, at synergy, at growth falter and fail and they look like gobbledegook, like nonsense. The important thing though for Te Reo Maori is to keep the spirit of innovation, of experiment and chance going and not to retreat into mindless language conservatism.

I koonei he koorereo moo ngaa hononga i waenganui i te ao paho me ngaa waahi koorero Maaori peenaa i te Whare Paremata. Ko te whakaaro ki koonei he mea nui eenei 
hononga hou moo te whakatipuranga o te reo. Kei runga, kua koorerongia te mea e moohiotia pea ko te 'hyperlink', te hononga o teenaa wao ki teenaa maa, me kii, te ipurangi. Ka rapua e Koro Wetere he ture tawhito moo te reo ki roo Paremata. Ka timata mai te Pouwhakaata Maori. Ka hono eenei mea, aa, kua tukuna teetahi kaha moo te reo ki te ao ki teenaa aahua paho, teenaa hoki.

Here attention has been given to combinations, new combinations between, say, media and areas where language is spoken such as parliament. It has been argued that these new combinations are critical in language development. Attention has been given above to what might be called the hyperlink where one dimension links to another via, perhaps, the internet. Koro Wetere finds a loophole to an obscure rule about translation in parliament. Maori Television starts and there is a need for news feeds of the kind that parliament can supply. These two areas are linked and there is a language force unleashed. That force has something of a hyper effect as the internet and various media are brought into play.

E taea te koorero moo enei mea e iwa hai puunaha, hai mea motuhake raanei. Ka koorero te Haahi Ratana mo ngaa morehu, ngaa mea e tika ana kia kohia anootia e Wiremu Tahupotiki Ratana (1963). I te Maataawai me te Rautaki Reo Maaori hoki he whakaaro ki reira moo eetahi puunaha, io raanei moo te reo. Kei nga iwi eetahi puunaha, kai te kaawanatanga eetahi. Ka paataingia teenei moo te iwi e Karetu. Engari e tika ana kia paataingia hokitia ngaa tari kaawanatanga moo nga puunaha ki reira. Ka whakaaro anootia te hoohaa o Tawhiwhirangi moo te kaawanatanga. Ka whakaarongia he kauwhata engari ko te whakaaro peenaa moo te reo he mea rawekeweke pea teenaa. Ko ngaa mea taea ki te waa tonu, kaaore he tauira, kaaore he puunaha, he mea hou kee raa i eetahi waa.

It is possible to look at the nine or so areas in terms of systems or in terms of disparate items. The Ratana movement 
spoke of morehu, remnants, the disparate items that Ratana the prophet wanted to pick up and put togetgher again (Henderson1963). In Te Maataawai and Te Rautaki Reo Maori there is an implication of systems when it comes to language. The iwi are ascribed systems of language renewal that critics such as Karetu seem to be questioning and there is an idea that the systems set in place by the language bureaucracies of the state will work. There is an order assumed but assuming order in language is inherently problematic. What works in the moment sometimes has no precedent, belongs to no system and is, in a word, random.

Kai te haere te reo $\mathrm{i}$ te aroaro kee o te tangata. kaaore he mea hinengaro i eetahi waa. ka taea te koorero i te wa tonu. E tika ana kia whakahokitia te reo ki te whenua, aa, e tika ana pea kia rapua ngaa mea tata ki te tangata hai mea tautoko i te reo. Ko te ao rorohiko, te ao pere me te ao ipurangi eetahi waahi whakatipu pea i te reo (McKenzie et al). Teeraa pea ko ngaa mihini e koorero Ingarangi ana inianei, e tahuritia eenaa hai mea koorero Maori.

Language works in close. It is not always a reflective, cerebral matter. Language happens in the moment without thinking about it. Things need to be grounded and there may be a need to look for 'surrounds', places and occasions where people are surrounded by the reo. The use of artificial languages and intelligence has been mentioned and there have been references to apps that support the language in various ways (cf McKenzie et al 2014). There is no reason why we can't have the machine tell us when to pay and for it to call out for a supervisor in Maori at the checkout if we elect to do so.

Kaaore i te tika pea kia whaia anootia ngaa reo koorero o neheraa. he mea pai kee teenaa moo nga whare taaonga. Engari kia ora ai te reo e tika ana pea kia whaingia ngaa puu kaha hou. 
Revitalization might be a misplaced term. If the intent is to restore a vitality that once was then that might be fine for historical or museum studies. But for a language to live there has to be a search for the new, for new sources of energy.

Ko teetahi mea ki runga ko te koorero moo te kaha o nga roopu reo mai $\mathrm{i}$ te reanga teitei. Teeraa pea e tika ana kia paataingia anootia i te rawa me te aro o eenei roopu.

One matter that has been studied above is that of elites and the power of language elites. Perhaps it is worth asking in this conclusion about the value and direction of these groups.

Ko teetahi mea ko te mahi koorero i te waa tonu, te reo o naaiatonumainei me ngaa mea e aarai ana $i$ te haere o te reo koorero. He tauira o eenaa pea ko ngaa kaipaneke ki te whare paremata me ngaa tuhinga ki raro i te pouwhakaata.

There is also an emphasis on the immediacy of te reo and the inhibitory factors involved in language hesitancy. Examples of the latter might include mandatory translators in parliament or subtitles on television

Kia hoki ai au ki tooku waa tiimata e tika ana kia arotakengia tonutia te reo i nga waa katoa meenaa ko teenaa taahau naa mahi. Kaaore he whakautu kootahi. Engari raa, he rarangi roa moo ngaa whiringa, he aawangawanga moo eetahi tatanga. E tika ana kia whai ai te tangata i ngaa hononga pai. Whaia te wana, whaia te kaha i te waa koorero tonu. Iriringia raa te reo hai whakakai e tiahoaho naa i eetahi waa, hai whakakai mapihi engari raa he whakakai o te waa tonu e werawera mai ana ki te taringa i eetahi waa.

To come back to where I started, the way you wear the language needs constant review if you speak it for a living. There is no magic bullet, no great plan. But there is a range of options and there are dangers in certain approaches. There are combinations to be on the alert for. Follow the excitement, 
follow the energy of te reo as it happens. Wear it the language as an ornament that sometimes sparkles, an ornament, ultimately, of grace but also an ornament of the moment that sometimes burns in the ear. 


\section{Bibliography}

Acosta, Margarita 2009 Language minorities developing multiple literacies; Additive Bilingual Education and Transformative Pedagogy Swarthmore College Unpublished Masters Thesis

Baker and Jones 1998 Encyclopedia of bilingualisn and bilingual education Frankfurt, Multilingual Matters, (cited in Ngapo, Korohere 2014:185)

Barber, Benjamin R 1995 Jihad vs. McWorld", Hardcover: Crown, 1995

Barber, Keith, 2006. Breaking the consensus: The politicisation of Maori Affairs. SITES 3(1):5-20

Barton B and Cleave P 1989 Nga kupu tau ahuatanga Auckland College of Education

Bereiter, C. and M. Scardamalia (1987a) An attainable version of high literacy: approaches to teaching higher order skills in reading and writing. Curriculum Inquiry 17:1

Bereiter, C. and M. Scardamalia (1987b) The psychology of written composition. Hillsdale, N. J.:Erlbam

Beykont, Z.F. (1994) Academic progress of a non dominant group: A longitudinal study of Puerto Ricans in New York City's late exit bilingual programs. Unpublished doctoral dissertation, Graduatre School of Education, Harvard University

Bonbright J and Bradley, K, 2013 Evidence: A Report on the Impact of Dance in the K-12 Setting, National Dance Education Organization

National Endowment for the Arts

Brown, Michael F 2004 Who owns Native Culture, Harvard University Press

Cleave P 1975 Wai Maori, Wai Tai, University of Waikato Maori Dept Working Paper

Cleave, Pere and Mataira, 1977 The Oxford Picture Dictionary

Cleave Peter 1980 Sounds particles and parts of speech, Department of Sociology Working Paper, University of Waikato

Cleave 1999 Ka hao te kupenga hiko

He Tuhinga Aronui: the Journal of Maori Writing, ed Moon,P AUT

Cleave Peter 2001 The Nurturing Shield, a collection of essays on the Maori Language Campus Press

Cleave Peter 2009 Starting Points, Campus Press

Cleave Peter 2009 Iwi Station, Campus Press

Cleave Peter 2010 Te haere o te reo Campus Press

Cleave 2010 Seen heard written read, tekaharoa.com

Cleave P 2011 Whenua ma wai tekaharoa.com

Cleave, Peter 2014 Memory, Body and Dance, a literature review tekaharoa.com

Collier, Virginia P. 1987. Age and rate of acquisition of second language for

academic purposes. TESOL Quarterly 21, 617-641

Crystal, David. 2000. Language death Cambridge University Press 
Coulon, C 1978 French Political Science and Regional Diversity in Ethnic and Raciasl Studies.ed Stone, J Vol 1 No 1. Routledge and Kegan Paul, January 1978

Cummins J 1996 Negotiating Identities:education for empowerment in a diverse society Ontario: California Association for Bilingual Education

Cummins, Jim. 2000. Language, power, and pedagogy : bilingual children in the

crossfire Clevedon [England] ; Buffalo [N.Y.]: Multilingual Matters.

Fishman, Gella Schweid and Charity Njau. 2012. Joshua A. Fishman bibliography (1949-2011). International Journal of the Sociology of Language 213: 153-248

Flavell Te Ururoa 2014 Te Reo Maori $i$ te Whare Paremata in Higgins et al ed. pp99-108

Foote, K. 1997 Shadowed ground: America's landscapes of violence and tragedy. Austin: University of Texas Press

Francis Fukuyama 1992 The End of History and the Last Man. Free Press.

Foucault, Michel 1969. The Archaeology of Knowledge, Routledge, 2002

Goldsmith, M 2011 Who Owns Native Nature? Discourses of Rights to Land, Culture, and Knowledge in New Zealand International Journal of Cultural Property. Vol 18, Special Issue 03 August

Henderson, James Mcleod 1963 Ratana The Man, The Church, The Movement (1st ed.) A.H \& A.W. Reed

Higgins, R, Rewi P and Olsen-Reeder V 2014 The value of the Maori Language, Te Hua o te Reo Maori Volume Two Huia Publishers

Jackson, M 1967 Literacy, communications and social change unpublished Master of Arts University of Auckland

Higgins, Te Ripowai 2014 Kia Ora Tonu mo Ake Tonu E in Higgins etal ed. pp269-290

Hond (2002) Te Ataarangi Kura Takiwa promotional DVD (DVD segment)

Huizinga, J, 1970 Homo Ludens Paladin

Jackson, M 1967 Literacy, Communication and Social Change: The Maori Case 1830-1870 Unpublished MA Thesis, University of Auckland

Ka'ai, Tania 2004 Te mana o te reo me ngā tikanga: Power and politics of the language. In: Ki te whaiao: An introduction to Mäori culture and society. Pearson Education, Auckland, New Zealand, pp. 201213.

Karetu, Timoti 1993 Haka! The dance of a noble people, Auckland: Reed

Karetu, T 2014 Te Niho o te Ture Reo Maori in Higgins et al. ed 2014

Kawharu, Merata 2010 Environment as a marae locale, in Selby Moore and Mulholland Ed.

Keegan, Te Taka and Cunliffe, 2014 Young People,Technology and the Future of te Reo Maori in Higgins et al eds. pp385- 398

Levi Strauss, C 1966 The Savage Mind, University of Chicago Press 
Macleod, Jeremy Tatere 2014 He Hua Ranei To te Reo Maori mo nga Ra Kai te Heke Mai in Higgins et al ed pp141-150

McKenzie T, McCrae $\mathrm{H}$ and Toia, R 2010 (in press) ANYWHERE, ANYTIME- creating a mobile indigenous language platform. Ubiquitous Learning: An International Journal

McKenzie, Tabitha and Poia, Rewi 2014 The Road to Language Proficiency Is Always Under Construction, in Higgins et al ed. pp239-254

Mahuta, Robert 1974 Whaikoorero, a study of formal Maori speech, Master of Arts thesis, University of Auckland

Mahuta Ka'ai, R 2011 The impact of language loss on the performing arts tekaharoa.com Vol 4 No 1

Mane, Jo 2014 He Reo Tautoko: A History of Maori Broadcasting in Higgins et al eds pp319-330

Martin, J.R. 1991 Critical literacy: the role of a functional model of language. Australian Journal of Reading

Matthews, Nathan 2004, The Physicality of Māori Message Transmission- Ko te tinana, he waka tuku kōrero Junctures 3 December

Mataamua, R 2014 Te Reo Paapaaho me te Reo Maori: Maori Broadcasting in Higgins et al pp 331-348

May, S 2006 Language Policy and Minority Rights in T. Ricento An Introduction to Language Policy pp255-272 Oxford Blackwell cited in Higgins et al. ed 2014:32

Mazer, Sharon 2011, Performing Māori: Kapa Haka on the Stage and on the Ground, published in Popular Entertainment Studies (Vol. 2, Issue 1 , pp. 41-53)

Milroy James Te Wharehuia 2014 Matua Rautia nga Tamariki o te Kohanga Reo, in Higgins et al ed. pp 197-203

Moon P 2000 Maori transition to a literate society in the nineteenth century in The Nurturing Shield ed. Cleave Campus Press, Napier

Muller, Maureen and Kire, Andrea 2014 Kotahi Kapua ki te Rangi. He Marangai $\mathrm{ki}$ te Whenua: The Philosophy and Pedagogy of Te Ataarangi in Higgins et al eds. pp 291304

Mataira, K 1986 Nga Timatanga unpublished paper cited by Muller and Kire in Higgins et al ed 2014: 295-6

Ngapo, Korohere 2014, Te Nekunekutanga o nga Reo Taketake, in Higgins et al ed. 181-196

O'Regan, Hana 2014 Kia Matike, Kia Mataara: Te Huanui o Kotahi Mano Kaika in Higgens et al ed pp109-122

Ovando, C. J. and Collier, V. P. 1998 Bilingual and ESL Classrooms: teaching in multicultural contexts Boston: McGraw-Hill, 2nd Ed.

Parr C J, 'Maori literacy 1843- 1867 in Journal of the Polynesian Society, Vol 72, No 3 September 1963

Pulliam, H 1988, Sources, sinks and population regulation, American Naturalist 132 652-661

Putnam, R. D. (1976) The Comparative Study of Political Elites. Englewood Cliffs New Jersey 
Resnick, D.P. and L.B. Resnick 1977 The nature of literacy; an historical exploration. Harvard Educational Review 47: 370-385.

Ross, Mike 2014 He Reo Korero te Reo Mana in Higgins et al ed. pp169-180

Resnick, L. 1990 Literacy in school and out. Daedalus, 19(2), 169-185.

Rucksthul, Katharina, 2014 He Iho Reo in Higgins et al ed

Schama Simon 1995 Landscape and Memory Vintage

Selby R, Moore P, Mullholland, M 2010 Maaori and the environment:Kaitiaki Huia Publishers

Slaughter, H 1997 Indigenous language acquisition in Hawaii: a case study of Kula Kaipuni Hawai'i in Johnson and Swain eds Immersion Education:International Perspectives pp1-16 Cambridge University Press

Stephens, Mamari 2014 A House with Many Rooms: Rediscovering Maori as a Civic Language in the Wake of the Maori Language Act (1987) in Higgins et al. ed pp 53-84

Strong, M., Prinz, P 2000 Is American Sign Language Skill Related to English

Literacy? In Language acquisition, N.J.: Lawrence Erlbaum Associates pp131-142

Tawhai, Veronica W.H.2010 Rawaho, in and out of the environmental engagement loop in Selby, Moore and Mulholland ed pp 77-94

Tawhiwhirangi, Iritana 2014 Kua Tu Tangata E! Moving a critical mass, in Higgins et al ed. pp33-52

Taylor, Todd and Ward, Irene (eds) 1998 Theory in the Age of the Internet Columbia, UP

Temara and Mataamua in Selby R, Moore P, Mullholland, M 2010 Maaori and the environment:Kaitiaki Huia Publishers

Tittler, R, Fahrig, L and Villard, M Evidence of large scale source-sink dynamics and long distance dispersal among wood thrush populations, Ecology 87 3029-3036

Waho, Toni and Walker, Arapine 2014 Te Kura Kaupapa Maori 19852012 in Higgins et al. ed. pp 223-237

Watkinson, A and Sutherland, W 1995 Sources, sinks and pseudosinks in Journal of Animal Ecology 64 126-13

Whorf, Benjamin Lee. 1956. Language, thought, and reality : selected writings of

Benjamin Lee Whorf Cambridge, Mass.: Technology Press of Massachusetts Institute

of Technology (now MIT Press)

Winiata, Pakake 2014 Whaia te Ara a To Tupuna a Tawhaki: Whakatupuranga Rua Mana; He Mahere Whakapakari ki te Iwi in Higgins et al ed.151-168

Yates, B 1992 What is literacy? Auckland ARLA

Articles etc 
On Koro Wetere and Timoti Karetu by Wehipa Te Kanawa:307pm, Rā Apa 9 Paengawhāwhā 2014

On John McCaffery Radio Waatea April 5, 2014

Feature on broadcasters Te Karere April 152014

New Zealand Census 2014

http://www.miis.edu/academics/programs/langteachingspecializatio ns/lpa

http://www.radionz.co.nz/news/te-manu-korihi/237071/te-reoshould-fall-under-mlc-wetere

Te Karere on Ruakere Hond (21.5.14)

Workman Report 1998 